\title{
10. RESOLUTION GUYOT (HOLE 866A, MID-PACIFIC MOUNTAINS): FACIES EVOLUTION AND SEQUENCE STRATIGRAPHY ${ }^{1}$
}

\author{
Hubert M. Arnaud, ${ }^{2}$ Peter G. Flood, ${ }^{3}$ and André Strasser ${ }^{4}$
}

\begin{abstract}
Hole 866A on Resolution Guyot, in the Mid-Pacific Mountains, recorded a 1619-m-thick Hauterivian to Albian shallow-water carbonate sequence above volcanic basement, and overlain by a thin late Cretaceous to Cenozoic pelagic cap. Facies organization, geophysical log examination, and sequence stratigraphy interpretation give rise to a detailed history of the interplay of sedimentation and relative sea-level changes, and a comparison with that from other Lower Cretaceous platforms of the northern and southern margins of the Tethys. The Hauterivian to Aptian sequence consists of 19 depositional sequences, each characterized by transgressive systems tract, maximum flooding, and highstand systems tract. Four depositional sequence sets are distinguished. The first one corresponds to the Hauterivian sequences 1 through 4 . It is characterized by oolitic and oncoidal open-marine sediments, massive dolomitization, and a cyclic evolution, where the deepest water environments occur at the bottom and at the top of this sequence set (Hauterivian transgressions). Above an emersion horizon, which is probably related to a local uplift, the second set of eight Hauterivian to Barremian depositional sequences (sequences 5 through 12) is characterized by restricted subtidal to intertidal facies that display a general evolution grading from progradation to aggradation and a thickening-upward trend possibly related increased subsidence rate toward the top. The third sequence set consists of four Aptian sequences (sequences 13 through 16) characterized by open-marine facies, and a general deepening up to the lower/upper Aptian boundary. Two major maximum flooding surfaces could be identified. The upper one correlates with the Goguel level of southeastern France and the Selli level of central Italy. The fourth sequence set includes upper Aptian to Albian sequences 17 through 19, which are characterized by the abrupt return to restricted facies, implying a monotonous aggradation of swamp, marsh, and shallow-lagoonal sediments. The middle to upper Albian series correspond to an aggradational, then retrogradational, succession of sequences. However, owing to low recovery, this latter series could not be studied in detail.

A comparison of the sequence stratigraphic record is attempted between those at Resolution Guyot and other Lower Cretaceous platforms of the Tethys. Correlations are well constrained for the Aptian section. However, they are more tenuous for the Hauterivian and Barremian sections. The general sedimentary evolution at Hole 866A is similar to that of Tethyan platforms, as the same number of depositional sequences and maximum flooding events could be identified. This indicates that sedimentation on Resolution Guyot was influenced more by global sea-level changes than by local variations in subsidence rates.
\end{abstract}

\section{INTRODUCTION}

The Hauterivian to Albian sedimentary succession drilled on Resolution Guyot (Hole 866A) consists of a 1619-m-thick series of shallow-water carbonate overlying the volcanic basement (Fig. 1). During late Albian to Maastrichtian, the platform was subaerially exposed and karstified, and then drowned (Sager, Winterer, Firth, et al., 1993). Average recovery was low ( $15.4 \%$ for Hole $866 \mathrm{~A})$, but the cored material shows distinct patterns of facies evolution and meterscale sequences (Strasser et al., this volume). Interpretation of the downhole logs (gamma-ray and resistivity) gives indications for lithology (Cooper, this volume), sequential evolution and stratal pattern. Despite the punctuated recovery, the combination of core, facies, and log detailed descriptions, allows us to propose a sequence stratigraphy for the Hauterivian-Aptian interval and a comparison with platforms of the Tethys. The Albian section was not interpreted owing to low recovery. The comparisons are based on detailed published and unpublished data, not on the Cretaceous chronostratigraphy and cycles of sea-level change proposed by Haq et al. $(1987,1988)$.

\section{LITHOLOGY}

Using combined microfossil and macrofossil biostratigraphy, visual core descriptions, physical properties, and downhole logs, eight

\footnotetext{
${ }^{1}$ Winterer, E.L., Sager, W.W., Firth, J.V., and Sinton, J.M. (Eds.), 1995. Proc. ODP Sci. Results, 143: College Station, TX (Ocean Drilling Program).

${ }^{2}$ Institut Dolomieu, Laboratoire de Géodynamique des Chaînes Alpines, 15 rue Maurice Gignoux, 38031 Grenoble cedex, France.

${ }^{3}$ Department of Geology and Geophysics, University of New England, Armidale, N.S.W. 2351, Australia.

${ }^{4}$ Institut de Géologie, Université de Fribourg, Pérolles, 1700 Fribourg, Switzerland.
}

lithostratigraphic units were recognized above volcanic basement. In normal stratigraphic order (from bottom to top), the lithologic divisions are described as follows (Sager, Winterer, Firth, et al., 1993):

1. Unit VIII (1620.0-1399.7 mbsf). Dolomitized and undolomitized oolitic/oncoidal grainstone.

2. Unit VII (1399.7-1203.4 mbsf). Dolomitized oolitic/peloidal grainstone, oncoidal wackestone, and algal laminites, with clay/ organic-rich layers.

3. Unit VI (1203.4-791.8 mbsf). Cyclic packstone/wackestone with algal laminites, clay/organic-rich layers and patchy dolomitization.

4. Unit V (791.8-676.6 mbsf). Oolitic grainstone.

5. Unit IV (676.6-434.5 mbsf). Cyclic packstone/wackestone with scattered clay/organic-rich layers.

6. Unit III (434.5-19.6 mbsf). Wackestone and mudstone with common gastropods, benthic foraminifers, echinoids, ostracodes, sponges and dasycladacean algae.

7. Unit II (19.6-0.9 mbsf). Cretaceous manganiferous limestone.

8. Unit I (0.9-0.0 mbsf). Maastrichtian to upper Pliocene foraminiferal nannofossil ooze.

\section{METHODS}

\section{Facies Interpretation}

Facies definition in this study results from the detailed analysis of more than 630 thin sections provided by H. Arnaud, P. Flood, U. Röhl, and A. Strasser and from Ocean Drilling Program (ODP) thin sections made during the cruise. Bioclasts are numbered as rare $(<5)$, frequent (between 5 and 10 ), abundant (between 10 and 50 ) and very abundant $(>50)$. The change from restricted marine to open-marine environments is interpreted not only by facies modification, but also by the 


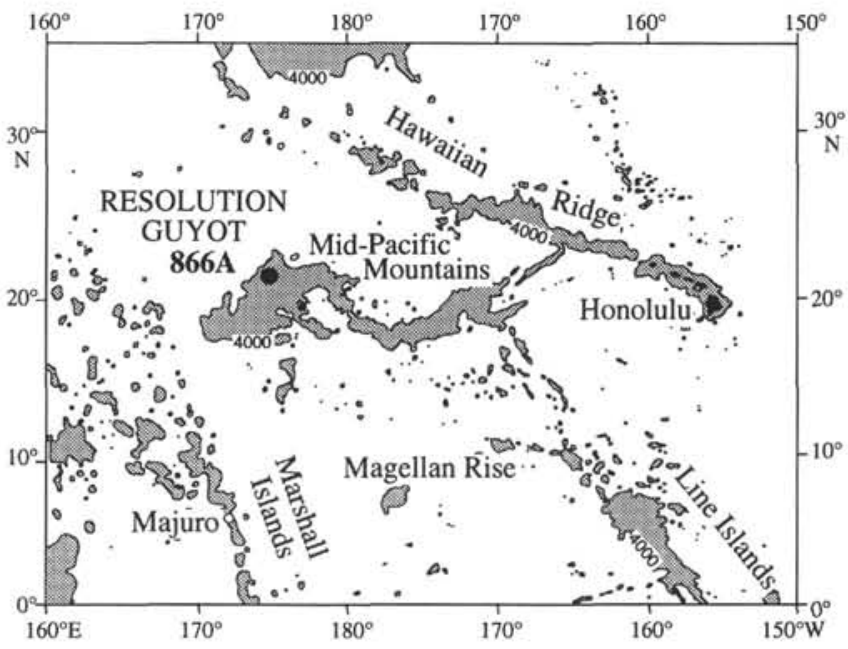

Figure 1. Location of Resolution Guyot at Hole 866A and principal seamount chains, western central Pacific Ocean basin. Stippled areas are shallower than $4 \mathrm{~km}$.

appearance of and increase in the number and diversity of foraminifers and metazoans, especially bryozoans, corals, and echinoderms observed both in cores and in thin sections.

Nineteen different microfacies have been recognized within sedimentary rocks recovered from Hole $866 \mathrm{~A}$. They are characterized by a set of diagnostic features, such as sedimentary structures, texture, composition, nature of bioclasts, and diagenetic overprint. These microfacies represent various depositional environments including open-marine shallow subtidal (facies 0 through facies 8 ), openmarine to slightly restricted subtidal environments (facies 9 through 12 ), restricted shallow subtidal to supratidal environments (facies 13 through 17), and emersion (facies 18). Continuous vertical or horizontal evolution from facies 0 to facies 19 has not been observed, thereby suggesting that lateral transitions between the various depositional environments were common. Consequently, the conventional succession of facies from deep and open to shallow and restricted (as listed in Figs. 4 and 6) does not have any paleogeographical significance. The vertical passage from an oolite (facies 2) to an emersion horizon (facies 18), for example, does not imply a major paleogeographical change. It simply expresses the shallowing-upward trend in a small-scale oolite sequence. The curve of vertical facies evolution shown in Figure 4 applies only to the evolution through time (shallowing or deepening) of one locality on Resolution Guyot. Even in the topmost part, where cores from Holes $867 \mathrm{~B}$ and $868 \mathrm{~A}$ are available, detailed lateral facies correlation is prevented by the absence of biostratigraphic markers.

\section{Core Interpretation}

Despite the low recovery in Hole $866 \mathrm{~A}$ ( $15.4 \%$ on the average), the vertical facies evolution could be reconstructed using the gammaray and resistivity logs together with the lithofacies analyses of the cored material (Cooper et al., this volume). Some cores had recoveries of $50 \%$ to $63.9 \%$, allowing for an interpretation of facies evolution with a high degree of confidence. The same interpretation could then be proposed for cores containing the same facies, but having low recovery. Cores having good recovery also permitted us to calibrate downhole logs with respect to the observed facies (Fig. 2). However, two difficulties of interpretation arise: (1) the textural variability within facies may cause variable responses in the logs, and (2) very thin layers of an otherwise well-expressed facies type (e.g., algalmicrobial mats) give a weakened log response.

\section{Sequence Stratigraphy}

Tectonic subsidence, eustatic change, volume of sediment, and climate control variations in sequences, stratal patterns, and facies distribution within carbonate rocks (Sarg, 1988). The most important are classically depicted as (1) the eustatic change and (2) tectonic subsidence, the combination of which produces a relative change of sea level that creates the space where sediments are deposited (Vail et al., 1981; Sarg, 1988; Van Wagoner et al., 1988). Depositional sequences consist of three parts, or systems tracts. The lowstand systems tract (LST) is deposited basinward on the previous bank margin and onlaps the platform landward. The transgressive systems tract (TST) is composed of a set of backstepping or retrogradational parasequences. On carbonate platforms, parasequence sets of the TST are characterized by opening up and/or deepening up of environments. Landward of the point where the LST pinches out, the lower boundary of the TST coincides with the unconformable portion of the sequence boundary, which consequently corresponds to generally significant lack of sedimentation. When the TST is thick and well developed on the platform, two parts are distinguished: the lower part ("keep-up") characterized by numerous aggrading thin parasequences with restricted-marine deposits and the upper part ("give-up") typified by thickeningupward and retrograding parasequences, where open-marine deposits appear and develop (Sarg, 1988; Jacquin et al., 1991). The top of the TST corresponds to the maximum flooding surface $(\mathrm{mfs})$ that is theoretically associated with a condensed section. Nevertheless, on carbonate platforms, except for drowned platforms, the maximum flooding does not correspond to a condensed section and is generally characterized by both more open-marine fauna and a more significant diversity of the fauna. The highstand systems tract (HST) is an aggrading, then prograding, unit that overlies the maximum flooding surface. On carbonate platforms, parasequence sets of the HST are characterized by shallowing-upward environments and appearance of restricted conditions. The boundary at the base of the HST is a downlap surface that commonly corresponds on platforms to an important facies change.

The sequence-stratigraphic interpretation of Hole $866 \mathrm{~A}$ is based on the following method:

1. Recognition of maximum flooding surfaces or intervals based on microfauna and macrofauna, suggesting the relatively most openmarine environmental conditions.

2. Identification of the vertical evolution of stacked parasequences that show a shallowing-upward (progradational trend) and that maintain facies, indicating more or less constant water depth (aggradational trend), or that display a deepening-upward facies evolution (retrogradational trend).

3. Recognition of sequence boundaries indicated by paleosoils or a change in stacking pattern of parasequences. Based on one hole only, and without knowing the geometry of the sedimentary bodies, the identification and precise location of sequence boundaries, in many instances, may be equivocal.

The vertical evolution of facies may vary significantly below and above sequence boundaries, depending on amplitude and rate of relative sea-level change (Fig. 3). Two cases have been encountered on Resolution Guyot:

1. Relative sea level is high during deposition of the highstand and does not fall below the platform rim. In this case, the highstand deposits exhibit an open-marine subtidal facies, the sequence boundary is only weakly marked, and the following transgressive deposits are characterized by restricted subtidal to supratidal deposits. Facies generally remain restricted and shallow, because sedimentation can keep up with the rise of sea level.

2. Water depth is very shallow during highstands, leading to restricted subtidal to intertidal deposits. Sea level then drops well 


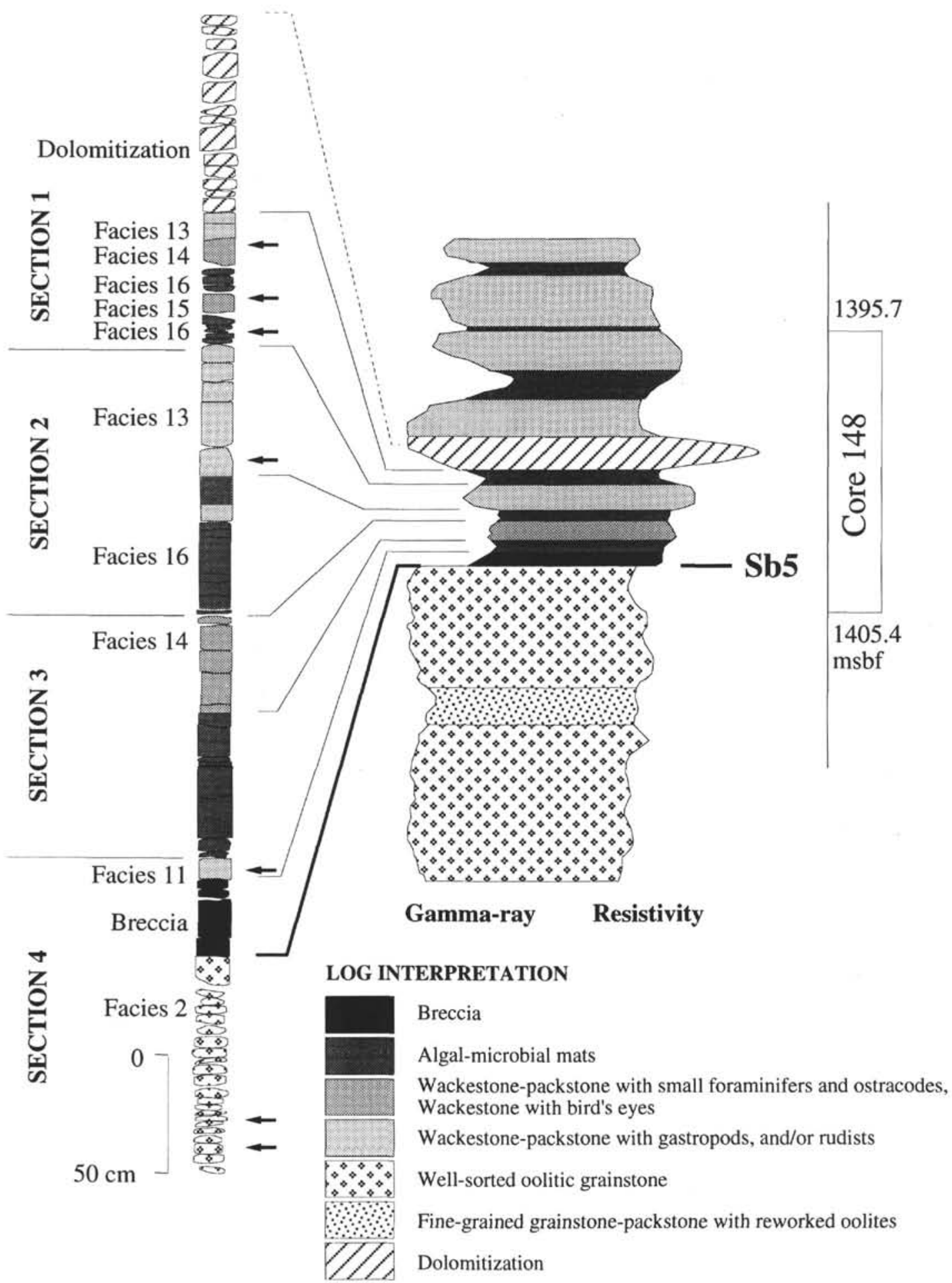

Figure 2. Correlation of recovered material and downhole logs in the case of Core 143-866A-148R. Definition of facies is based on visual core description and on thin sections (arrows). Facies 2 = well-sorted oosparites; Facies $11=$ pelmicrites with gastropods; Facies $13=$ micrites with ostracodes and small benthic foraminifers; Facies $14=$ micrites and pelmicrites with bird's eyes; Facies $15=$ micrites and pelmicrites with oncolites; Facies $16=$ micrites and pelmicrites with algal-microbial mats. Facies changes recognized in the cored material are tentatively correlated with changes in log response. The nonrecovered part of the core is interpreted by assuming that similar facies cause similar log response. Convergences, of course, cannot be excluded. 


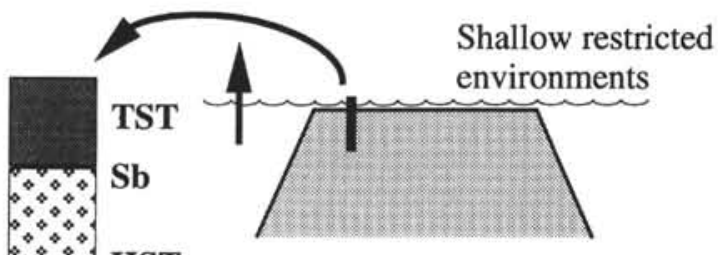

HST
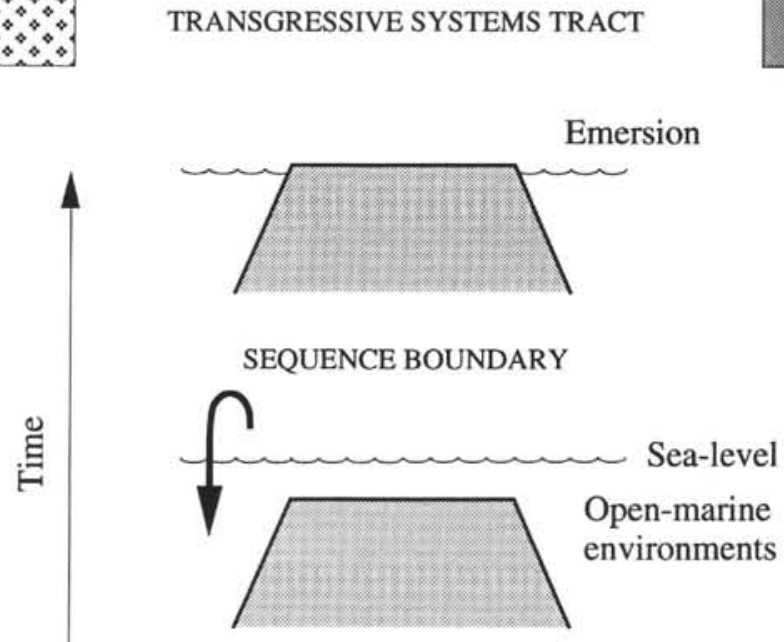

HIGHSTAND SYSTEMS TRACT

1

Open marine

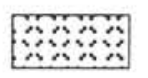

Open-marine

(transgressive facies)

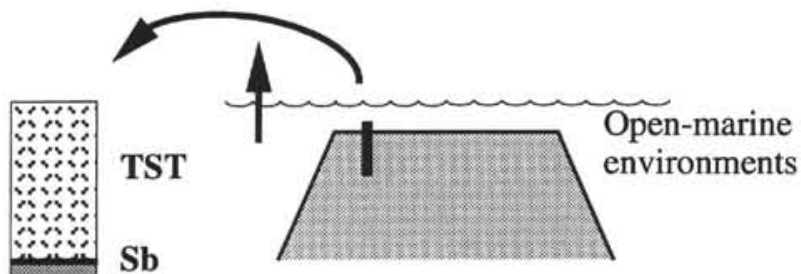

HST TRANSGRESSIVE SYSTEMS TRACT

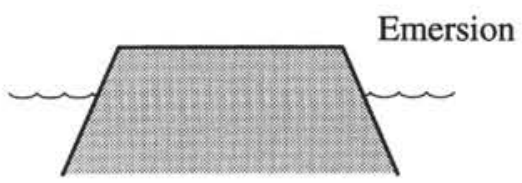

SEQUENCE BOUNDARY

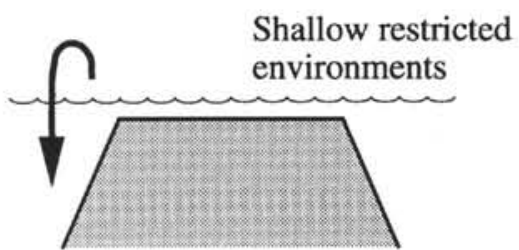

HIGHSTAND SYSTEMS TRACT

2

Slightly restricted shallow marine
Restricted shallow marine

Figure 3. Evolution of facies on a platform top as function of initial water depth and amplitude of sea-level fluctuations. For discussion refer to text.

below the platform rim to form a clearly defined sequence boundary. The platform top is not flooded again until late during the following transgression, and open-marine subtidal facies containing reworked material are deposited. If the amplitude of sea-level fluctuation is high, significant erosion may take place at the sequence boundary, and relatively deep transgressive facies may directly overly relatively deep facies of the early highstand.

\section{MICROFACIES TYPES}

Microfacies of the carbonate rocks recovered from Hole 866A have been grouped into 19 families that represent sediments deposited in various environments. Facies 0 through facies 8 characterize open-marine shallow subtidal environments, facies 9 through 12 are typical of open-marine to slightly restricted subtidal environments, facies 13 through 17 indicate restricted shallow subtidal to supratidal environments, and facies 18 characterizes emersion levels.

\section{Facies 0: Fine-grained Pelsparites}

Facies 0 (Pl. 1, Fig. 1) has been encountered only in a few beds belonging to Units V through VIII.

Facies 0 corresponds to massive, very well- to well-sorted grainstones and less common packstones-grainstones. Gastropods and rudist shell fragments (Core 143-866A-125R) were observed. The sediment consists of very small-sized peloids, ooids, and rounded bioclasts. Where they are abundant, ooids show only one thin irregular calcitic lamina around the nucleus (superficial ooids, Purser, 1983).
Lithoclasts and small rounded oncoids are minor components. Macrofauna is represented by mollusk fragments (gastropods and bivalves), small pieces of arthropods, echinoderm plates (including crinoids), and very rare bryozoan fragments. Green and red algae are very rare. Small benthic foraminifers are commonly abundant or very abundant.

Facies 0 generally grades into oolitic limestones (facies 1 or 2 ) or rudist rudstones and grainstones (facies 7 ). The sediments were reworked and probably deposited by currents in shallow subtidal openmarine water. Two different depositional environments are suggested: the first one appears to be the distal part of oolitic sand bars, whereas, the second represents the distal part of washover fans deposited by storm currents in various environments. In the latter case, compositional elements come not only from open-marine, shallow subtidal environments, but also from more restricted settings.

\section{Facies 1: Peloosparites and Oopelsparites with Reworked Ooids}

This facies (Pl. 1, Fig. 2) is known in Units V and VIII, and in Subunits VIC, VIIA, and VIIB, where it generally grades vertically into facies 2.

Facies 1 corresponds to massive, generally well-sorted and burrowed peloidal-oolitic grainstones or less common packstones levels. Small gastropods are generally present to abundant. Large oyster shell fragments occur at some levels. This sandy sediment consists of peloids, reworked ooids, bio- and lithoclasts, but lithoclasts are always a minor component. Ooids are abundant and predominant in some sediments. Metazoan clasts and foraminifers are represented 
both as bioclasts and as nuclei of ooids. Arthropod fragments are common in Unit VIII, but disappear upward. Echinoderm plates, represented both by echinoids and crinoids, are abundant. Bivalve and gastropod fragments are generally abundant, including rudist clasts in some levels (e.g., radiolitids in Core 143-866A-79R). Corals are absent to rare. Green algae (Terquemella, Boueina, Cylindroporella) are present; however, they are generally rare. Small benthic foraminifers (miliolids, textulariids, nodosariids, Lenticulina, Nubecularia, large agglutinoid forms, and Placopsilina) are generally abundant to very abundant. Bioturbation is common. Thin fringing cement occurs locally, suggesting early marine cementation (Röhl and Strasser, this volume).

Facies 1 represents an open-marine environment where reworked ooids mixed with bioclastic and peloidal sand in shallow water.

\section{Facies 2: Well-sorted Oosparites to Oomicrites}

Facies 2 occurs in Unit VIII (Cores 143-866A-70R through-149R), Subunit VIIC (Core 143-866A-143R), Subunit VIIA(Core 143-866A129R), Subunit VIC (Cores 143-866A-126R, -121R, and -119R), Subunit VIC (Core 143-866A-102R) and Unit V (Cores 143-866A-73R to $-82 \mathrm{R})$. However, the most important development of this facies corresponds to the two main oolitic intervals (i.e., Units VII and V).

Facies 2 (Pl. 1, Fig. 3) is a massive, well- to very well-sorted, planar horizontal to oblique laminated oolitic grainstone to packstone. Keystone vugs are observed at some levels. Hardgrounds are commonly found at the top of small-scale sequences, bored by bivalves and encrusted by serpulid worms and oysters. The sediment consists mainly of spherical, small- to medium-sized ooids (Jenkyns and Strasser, this volume). Small peloids, intraclasts, and grapestone fragments are generally present as minor components. Early marine cementation by a fringing cement is common, and many intraclasts correspond to an early-cemented oolitic grainstone. A second-generation blocky calcite cement occurs in a few samples, suggesting early, freshwater percolation (Röhl et al., this volume). Macrofauna is represented by a few corals, chaetetids, massive bryozoans, regular echinoids, and small gastropods (Unit VII). Small bioclasts act as nuclei of ooids. Small shell fragments (bivalves, gastropods, brachiopods) are common throughout. Echinoderm plates (crinoids and echinoids) are rare to abundant in Units V and VII, arthropod pieces are common (Unit VII), and rare bryozoan colonies are present. Green algae are rare to common (Terquemella common, Boueina and dasycladaceans, generally rare), and algal-microbial elements (Girvanella) are rare. Small benthic foraminifers (rare to very abundant) correspond mainly to smallsized miliolids, textulariids, Vercorsella, Melathrokerion, Glomospira, Valvulineria, Charentia, Protopeneroplis (Core 143-866A-149R). Volcanic glass fragments occur in Unit VII.

The faunal composition of facies 2 suggest a shallow, open-marine environment above the fairweather wavebase. Planar oblique laminations and keystone vugs indicate a beach deposit from offshore to foreshore (swash zone) (Inden and Moore, 1983). In such an environment, oolitic sands probably accumulated in sand bars (Halley et al., 1983).

Packstones or packstones-grainstones of Unit VI indicate a more quiet and perhaps less open-marine environments, as highlighted by the decrease of echinoid remains and benthic foraminifers.

\section{Facies 3: Peloosparites and Peloomicrites}

Facies 3 (PI. 1, Fig. 4), locally appears in Units V and VIC (Cores $143-866 \mathrm{~A}-120 \mathrm{R}$ to $-125 \mathrm{R})$. It consists of well to poorly sorted packstone or packstone-grainstone. It is characterized by the predominance of peloids and the significant decrease or disappearance of small benthic foraminifers (absent to rare). Peloids correspond to micritized or partially micritized bioclasts and ooids. Echinoderm plates (crinoids and echinoids), bivalves, and gastropods are abundant. Small, benthic foraminifers are rare.
Facies 3 is interpreted to have been deposited in shallow openmarine to slightly restricted subtidal environments. Remnants of openmarine organisms (echinoderms) are mixed with reworked peloids that correspond mainly to micritized ooids. The micritization of the ooids probably occurred during a relative sea-level fall when environments became more restricted than that of the previous open-marine oolitic sand bars. During periods of relative sea-level rise, these micritized ooids were reworked by currents and were mixed with clasts, such as echinoderm plates, which characterize more openmarine environments.

\section{Facies 4: Oo-oncosparites with Rounded Micritic Oncoids}

Facies 4 is common and predominant in some levels of Unit VIII (Cores 143-866A-168R to -152R), but it also occurs in Unit V (Cores $143-866 \mathrm{~A}-84$ to $-78 \mathrm{R})$. It commonly evolves or passes into facies 2 .

Facies 4 is a massive, well- to very well-sorted, commonly dolomitized oolitic-oncolitic grainstone to packstone in which oolitic sand was mixed with large, millimeter- to centimeter-size micritic oncoids (PI. 1, Fig. 5). In some cases (e.g., Core 143-866A-167R), graded-bedding appears, as the sizes of the oncoids decreases from centimeter- to millimeter-scale from the bottom to the top of meter-scale sequences.

The oolitic sand consists of spherical, small- to medium-size ooids, the nuclei of which are metazoan bioclasts (crinoid and echinoid plates, bivalves, gastropods, brachiopods, arthropods), green algae (Terquemella), algal-microbial lumps (Girvanella, Marinella), and small benthic foraminifers (textulariids, nodosariids, Lenticulina, Belorussiella, Nubecularia, Vercorsella, Sabaudia?, Melathrokerion, Valvulineria, Aeolisacus, Valvulineria). Unbroken large metazoans are absent. Early cementation is common. Small peloids, intraclasts, and grapestone fragments are present as minor components.

Millimeter- to centimeter-size oncoids occur as both minor or predominant components of facies 4 . They consists of several thin and regular laminae surrounding small-sized nuclei (bivalve shells, echinoderm plates, lithoclasts, or peloids) or mud pellets that were probably soft during sedimentation. In some cases, a void exists in the place of nuclei and these vugs may contain floating peloids or other clasts. Small-size oncoids are spherical and contain only one nucleus. Large oncoids have irregular shapes and are generally composed of two or several smaller oncoids, which shape the outermost laminae. In the largest oncoids, laminae may incorporate small peloids and other allochems (e.g., small benthic foraminifers). Some of these oncoids were broken in the early stage of their growth and the outer laminae seal the broken parts. Small oncoids occur in Unit V (size $<3 \mathrm{~mm}$ ), whereas the largest ones occur in Unit VIII (up to more than $2 \mathrm{~cm}$ diameter).

Mixing with open-marine oolitic sand, the presence of echinoderm plates or spines as nuclei, and the abundance of micritic nuclei suggest that sedimentation occurred in a quiet, shallow-marine environment, probably in a leeward position.

\section{Facies 5: Pelsparite and Pelmicrite with Echinoderm Plates and Small Benthic Foraminifers}

Facies 5 is known from Unit V and Subunits VIA, VIC, and VIID (PI. 1, Fig. 6). It corresponds generally to well-sorted and burrowed peloidal packstones. The sediment is a fine-grained sand or muddy sand composed of peloids as the major component and bioclasts. Reworked ooids are locally abundant in Unit V. Bioclasts are represented by rare arthropod remains and gastropods, abundant bivalve fragments, abundant to very abundant echinoderm plates (echinoids and crinoids), and small benthic foraminifers. Corals (Core 143$866 \mathrm{~A}-144 \mathrm{R}$ ) and green algae are rare. Keystone vugs are present at some horizons (Core 143-866A-125R). Some samples also contain grapestones and disseminated organic matter.

This facies indicates shallow, slightly restricted to open-marine environments. In Core 143-866A-144R, fine-grained peloidal sand 
with keystone vugs indicates the upper swash zone of a beach. In a few centimeter-scale intervals, grainstones grade upward into packstone exhibiting microbial laminations and bird's eyes, suggesting sandflat to intertidal mudflat depositional environments.

\section{Facies 6: Coarse-grained Biosparites with Rounded Elements}

Facies 6 (Pl. 1, Fig. 7), represented only in Unit V, is a porous, coarse-grained, skeletal grainstone made of large bioclasts and lithoclasts rounded by mechanical action as the predominant component, and ooids and small peloids as minor elements. Two grain sizes are predominant: (1) large, rounded bioclasts or lithoclasts, and (2) small peloids and some reworked ooids. Intraclasts are common and correspond to both mudstones-wackestones and grainstones. The latter may represent reworked pieces of beachrocks or hardgrounds. Large bioclasts correspond mainly to bivalve (including large rudists), gastropod, and coral fragments (or coral colony, Core 143-866A-79R). Dasycladacean algae, echinoderm plates, and small benthic foraminifers (miliolids and textulariids) are present, but not abundant. Bacinella oncoids are present in Cores 143-866A-75R and -79R. Large benthic foraminifers appear in this facies, but they are always rare and far less common than in similar facies of the Urgonian platforms, in the Tethys realm.

This facies suggests shallow and high-energy open-marine environments above the fair-weather wave base. Cores 143-866A-74R and $-75 R$ show that facies 6 appears in oolitic beach sequences (lower foreshore of Inden and Moore, 1983). In these small-scale sequences (Strasser et al., this volume), facies 6 corresponds to evenly laminated, well-sorted, coarse- to medium-grained grainstones interbedded with fine- to medium-grained oolitic grainstone that grade upward to keystone vug levels.

Facies 6 is similar to the coarse-grained skeletal grainstones well known from the Urgonian platform of the southeastern France (ArnaudVanneau and Arnaud, 1990).

\section{Facies 7: Coarse-grained Biosparites with Rudist and Gastropod Shells}

Facies 7 is present only in Subunit VIB (PI. 1, Fig. 8). It corresponds to porous, very coarse-grained, skeletal grainstone and rudstone composed of large, platy fragments of shells (mainly rudists and gastropods) and smaller rounded clasts. Large rudist (including caprinids) fragments are generally current-oriented, angular to slightly rounded, micritized, and partially dissolved. Well-preserved rudists, filled in by wackestone, exist in Core 143-866A-94. The internal sediment consists of micrite. Smaller clasts are commonly rounded and correspond mainly to recrystallized fragments of bivalves and gastropods. Small-sized peloids are ubiquitous. Reworked ooids occur in some levels. Echinoderm plates and small benthic foraminifers (Acruliammina, Nubecularia) are rare or absent. Green algae are absent, except in one thin section (two fragments).

The composition indicates that the coarse-grained particles came from shallow, subtidal, quiet environments where rudist communities were well developed. The large size of the rudists and the presence of caprinids, indicate that the environments was open-marine even though foraminifers and echinoderm plates are rare or absent. This facies is similar to those observed in rudist facies belonging to Lower Cretaceous carbonate platforms of the Tethys (Masse, 1976; ArnaudVanneau, 1980). Shell fragments and other clasts were possibly reworked by storm action and deposited on beaches and on washover fans.

\section{Facies 8: Pelbiomicrites and Pelbiosparites with Benthic Foraminifers}

Facies 8 (Pl. 1, Fig. 9) is well represented in Unit IV and appears also at several levels in Units V, VI, and VII, where it marks more open-marine levels, especially in the two latter units characterized by very restricted environments. It corresponds to fine-grained, poorly sorted peloidal wackestone to packstone characterized by bioturbation, micritized peloids, blackened peloids, intraclasts, and bioclasts, and abundant microfauna. Clays and disseminated organic matter are common. Glauconite occurs locally. Bioclasts include abundant fragments of bivalves, gastropods, and echinoderm plates; ostracodes and green algae are rare. Foraminifers are abundant to very abundant (more than 100 in many thin sections); they are well diversified and of both small and large sizes: miliolids (including abundant Istriloculina), textulariids, Debarina?, Valvulineria, and large benthic foraminifers, such as some miliolids, Vercorsella and orbitolinids (which appear in Unit IV).

Facies 8 is interpreted as having been deposited during rapid relative sea-level rises where open-marine waters cover the underlying environmentally restricted deposits and rework their compositional elements by wave and current action. The facies is similar to the so-called "transgressive facies" well-known in the Lower Cretaceous carbonate platform of the Tethys (Arnaud-Vanneau et al., 1987; Arnaud-Vanneau and Arnaud, 1990). It is characterized by the presence of clays, bluish color, rounded lithoclasts, and a mixture of bioclasts, reworking and mixing of microfauna (both from openmarine and restricted environments), and the presence of blackened or blue-gray compositional elements.

\section{Facies 9: Micrites and Pelmicrites with Cayeuxia, Sponge Spicules, and Large Benthic Foraminifers}

Facies 9 (PI. 1, Fig. 10) is well represented in Unit III. It occurs less commonly with minor differences in Unit IV and Subunits VIB and VIID. It is a poorly cemented, poorly sorted mudstone to wackestone characterized by gastropod shells, open burrows usually filled in by large fecal pellets, and large, complex foraminifers (only in Unit III). Micritized peloids are abundant in some levels. Cayeuxia-like large algae are abundant and partly or totally dissolved in many samples. Green algae are rare or absent. In Subunits VIB and VIID, Bacinella oncoids occur sporadically in this facies (e.g., in Core 143-866A144R). Gastropod shells are frequent. Rudist fragments were observed in Core 143-866A-46R. Ostracodes and foraminifers are generally abundant, the latter represented both by small-sized and by large and complex species: textulariids, miliolids (including Istriloculina), verneuilinids, Vercorsella, Cuneolina, Valvulineria, Arenobulimina. In Unit III, large sponge spicules are abundant.

Facies 9 indicates normal-marine to slightly restricted shallow subtidal environments characterized by low- to very-low energy in a protected and quiet lagoon that was probably located behind beaches or sand bars. In Unit III, facies 9 generally is associated with facies 10 (wackestones with large foraminifers), and with exposure surfaces displaying incipient calichification (Sager, Winterer, Firth, et al., 1993).

\section{Facies 10: Micrites and Biomicrites with Large Foraminifers}

Facies 10 is well represented in Unit III (a slightly different facies occurs sporadically in the upper part of Unit IV). It corresponds to a poorly cemented and poorly sorted mudstone-wackestone characterized by gastropod shells (abundant small nerineids), open burrows commonly filled in by large fecal pellets, and large, complex, foraminifers. Facies 10 is similar to facies 9 for most of the components except for the absence of the large Cayeuxia-like green algae. Gastropod shells are frequent, commonly dissolved, and represented by open molds. Ostracodes are generally abundant. Large sponge spicules usually exist in Unit III. Foraminifers are abundant and diversified, and represented both by small, as well as, large and complex species: textulariids, miliolids (including Istriloculina), verneuilinids, Vercorsella, Cuneolina, Valvulineria, Everticyclammina, Nezzazata, and orbitolinids (which have been found only just above and 
below the boundary of Units III and IV, from Cores 143-866A-46R to-56R; Pl.1, Fig. 11). Palaxius microcoprolites occur in some levels.

This facies suggests normal to slightly restricted shallow subtidal environments characterized by low to very low energy. It probably corresponds to the same depositional setting as facies 9 but somewhat less restricted.

\section{Facies 11: Micrite and Pelmicrite with Rudists and Gastropods}

Facies 11, common in Unit VI, is a generally well-cemented, poorly sorted mudstone-wackestone characterized by rudist shells (Pl. 2, Fig. 1), gastropods (including large nerineids), and some Gervillia bivalves. Rudists occur locally in life position, with the two shells connected; some are identified as large caprinids, typical of open-marine or slightly restricted, shallow environments. Large, open burrows are partially filled in by ovoid fecal pellets, as are the rudist shells, or by peloidal wackestone-packstone. Small benthic foraminifers (miliolids) are rare or absent. Dasycladacean algae were observed in some samples, but generally they are very rare.

This facies corresponds to rudist bioherms or environments close to rudist bioherms, which indicates quiet and shallow subtidal openmarine to slightly restricted conditions. Facies 11 is similar to the well-known rudist facies of the Urgonian platform (Masse, 1976; Arnaud-Vanneau, 1980).

\section{Facies 12: Micrite and Pelmicrite with Green Algae}

Facies 12 is present from the top of the carbonate series (Unit II) to Unit VI (PI. 2, Fig. 3). Samples belonging to this facies are rare owing to poor recovery in the upper part of Hole 866A.

Facies 12 corresponds to generally well-cemented, poorly sorted mudstone-wackestone to wackestone-packstone characterized by abundant green algae (Terquemella and dasycladaceans). Bivalves fragments (including rudists, gastropods) and benthic foraminifers (including large foraminifers in Unit III) are rare to abundant. Large sponge spicules occur in Core 143-866A-89R and Palaxius microcoprolites in Core 143-866A-103R.

This facies, which is generally associated with facies 10 and 11 , indicates the same quiet, shallow subtidal environment. It is probably somewhat more restricted as indicated by the decrease or disappearance of rudists and large foraminifers. In some cases, facies 12 has been found at the top of small-scale sequences, below well-lithified exposure surfaces bored by bivalves.

\section{Facies 13: Micrite with Ostracodes and Small Benthic Foraminifers (Istriloculina)}

This facies is common in Units II and IV and Subunit VIC; it occurs less commonly in Subunits V, VIA, and VIID.

Facies 13 (Pl. 2, Fig. 4) corresponds to generally poorly cemented and poorly-sorted mudstone-wackestone that are intensely burrowed and characterized by abundant ostracode valves. Partial dolomitization occurs in some levels. Small benthic foraminifers are usually rare, and are represented mainly by small miliolids (Istriloculina) and rare textulariids, Valvulineria (Core 143-866A-60R), Arenobulimina, and Vercorsella (Core 143-866A-63R). Rare gastropods occur, especially in Unit III. Charophytes have been found in Sample 143-866A76R-1, 139-141 cm. Possible bird's eye structures appear in some levels. In Unit IV to Unit VII, facies 13 is commonly represented by peloidal wackestones, partially dolomitized, with mottled burrows (burrows are often filled in by fine peloidal packstone), finely dispersed organic matter, and poorly preserved microbial laminations. Bird's eyes and desiccation cracks that were not observed in thin sections occur at some levels. In Unit III, facies 13 corresponds mainly to mudstone-wackestone, with large, open burrows filled in by fecal pellets.
This facies suggests quiet, very shallow, subtidal to intertidal restricted environments based on the presence of ostracodes and Istriloculina, typical of restricted waters. It appears that the depositional environment of facies 13 was somewhat less restricted in Unit III. It relates more closely to facies 10 and 11 than in the underlying units, where algal-microbial mat levels are well developed.

\section{Facies 14: Micrite and Pelmicrite with Bird's Eyes}

Facies 14 is relatively common in Units VI and VII. It corresponds to samples with well-developed bird's eyes (PI. 2, Fig. 5). However, it does not exhibit typical algal-microbial mats (facies 16). Two different subfacies were distinguished. The first one, which is similar to facies 13 and corresponds to wackestones with well-developed bird's eyes, ostracodes and small benthic foraminifers (mainly Istriloculina). The second one, similar to facies 16 (algal-microbial mats), is represented by burrowed peloidal wackestone with reworked elements (partly micritized ooids, and echinoderm plates), burrow mottles, and finely dispersed organic matter throughout. Foraminifers are represented by textulariids, Valvulineria, and predominant miliolids (Istriloculina). Rare green algae (Terquemella) occur in some levels. Bivalves and gastropods are rare.

This facies, typical of restricted intertidal environments (Shinn, 1983), is associated with facies 13 and 16 in small-scale lagoonalperitidal sequences (Strasser et al., this volume). It is also wellknown in Lower Cretaceous Urgonian platforms (Arnaud-Vanneau and Arnaud, 1990).

\section{Facies 15: Micrite and Pelmicrite with Oncolites}

Facies 15 is not well represented in samples from Hole 866A. It occurs only in thin levels within Subunits VIA, VIC, VIIA, and VIID (PI. 2, Fig. 6). The burrowed, partly dolomitized, poorly sorted peloidal packstones-wackestones are characterized by the presence of middle-sized and relatively rare micritic-algal oncolites. Among the rare bioclasts are small fragments of bivalves and gastropods, and small benthic foraminifers (absent to abundant). Ostracodes are locally found in abundance. Cayeuxia-like algae and Bacinella are present at some levels. Micritized peloids are predominant. Spherulites of probable microbial origin are present at some levels.

Facies 15 suggests quiet and restricted, very shallow, subtidal to intertidal environments. In Core 143-866A-131R, small-scale sequences are similar to that of the Urgonian platform in southeastern France (Arnaud-Vanneau and Arnaud, 1990). From bottom to top it consists of packstone-wackestone with small rudists, wackestonepackstone with oncolites, and algal-microbial mats levels. Nevertheless, as in the Lower Cretaceous carbonate platform of Central Italy, Resolution Guyot is characterized by an important development of the algal mat facies, which contrasts with an oncolytic facies that corresponds to less quiet environments.

\section{Facies 16: Micrite-Pelmicrite and Dolomicrite-Dolopelmicrite with Algal-Microbial Mats}

Facies 16, one of the most conspicuous in samples from Hole 866A, is well represented in Units IV to VII, especially in the lower part of Unit IV and in Subunits VIA and VIIA, as part of lagoonal-peritidal small-scale sequences (Pl. 2, Fig. 7). The poorly sorted, partly dolomitized wackestones-packstones are characterized by algal-microbial mats, and finely dispersed organic matter or organic-rich laminae. Bioturbation, flat pebbles, tepees structures, bird's eyes, and incipient desiccation cracks are common at some levels. Stromatolites were observed in Core 143-866A-109R (Sager et al., 1993). Thrombolitic frameworks, and spherulites of microbial origin are common (Strasser et al., this volume). Bioclasts are absent or rare, and when present, they are represented by small-sized gastropod fragments, ostracodes, and 
small benthic foraminifers: Istriloculina, Valvulineria (Cores 143 866A-66R, -87R and -119R), Glomospira (Core 143-866A-98R), and Aeolisacus (Core 143-866A-98R). At some levels, thin peloidal packstones are interbedded with algal mat layers; they may represent storm layers.

Facies 16 indicates quiet, restricted to very restricted, shallow subtidal to intertidal-supratidal tidal flat environments (Shinn, 1983). It is generally associated with exposure surfaces showing desiccation cracks.

\section{Facies 17: Micrite and Dolomicrite with Thin Sedimentary Laminations}

Facies 17 (Pl. 2, Fig. 8) is well represented in the lower part of Unit IV and in Subunit VIC as parts of lagoonal-peritidal sequences. The mudstones-wackestones, with some partial dolomitization, are characterized by alternations of thin, parallel to undulated sedimentary laminations and orange to brown organic-rich laminae. Finely dispersed organic matter particles, bioturbation, and mottled burrows occur at some levels. Clay seams and peloids are generally abundant. Pseudomorphs of gypsum exist in Cores 143-866A-89R, -99R, $-102 R,-107 R$, and $-109 R$. Anhydrite pseudomorphs may also occur, but have not been positively identified. Bioclasts are absent or represented only by rare to abundant ostracodes.

Facies 17 is generally related to facies 16 and 18 . It represents supratidal marsh environments where hypersaline conditions develop locally and periodically. Differences probably exist between the Unit IV and Subunit VI environments, as the former probably correspond to marshes as evidenced by the coalified plant fragments that were observed (Sager, Winterer, Firth, et al., 1993, p. 198, Core 143-866A$62)$, whereas, the latter may belong to more hypersaline deposits, as indicated by the presence of gypsum (PI. 2, Fig. 9), lack of bioturbation, and the greater regularity of sedimentary laminae disposition.

\section{Facies 18: Micrite with Desiccation Cracks}

Facies 18 includes several samples similar to those of facies 14 to 16 (Pl. 2, Fig. 10). It is well represented in Unit VI (Subunits VI A and VIC). Facies 18 corresponds to a mudstone-wackestone with desiccation cracks, bird's eyes, and locally brecciated levels. Pseudomorphs of gypsum occur frequently. Early dissolution of gastropod and bivalve shells is common. Bioclasts are absent or rare, and are represented by ostracodes, small benthic foraminifers (Istriloculina), and sporadic green algae (Terquemella in Core 143-866A-89R).

Facies 18 characterizes cemented supratidal crusts and exposure surfaces on the top of small-scale peritidal sequences. Pseudomorphs of gypsum may indicate periods of dry climates.

\section{DEPOSITIONAL ENVIRONMENTS AND SEQUENCE STRATIGRAPHY}

The facies analysis provides a basis for the interpretation of depositional environments. A variety of depositional environments are represented within the Hauterivian-Albian stratigraphic section encountered within Hole 866A. They range from: (1) open marine environments (Unit VIII, Cores 143-866A-148R to -171R), (2) restricted shallow subtidal to supratidal environments (Subunit VIC [part] and Unit VII, Cores 143-866A-103R to -148R), (3) restricted to open, shallow marine transgressive (Unit V, Subunits VIA, VIB, VIC [part]; Cores 143-866A-73R to $-103 R$ ), (4) shallow marine to restricted subtidal-intertidal flats and marshes (Unit IV, Cores 143-866A-48R to $-73 R$ ).

Combining the microfacies analysis and the geophysical logs of the Hole 866A, 19 distinctive depositional sequences have been recognized within these four depositional settings. They have been interpreted using sequence stratigraphy methods (Vail et al., 1981; Sarg, 1988; Van Wagoner et al., 1988).
Sequence boundaries are indicated by paleosoils or a change in stacking pattern of parasequences. Maximum of deepening of the environments are interpreted as mfs. Parasequence sets have been assigned to the different systems tracts (TST, HST) that occur on Resolution Guyot, according to the general deepening up or shallowing up trends. The resultant vertical stratigraphic record in the Hole $866 \mathrm{~A}$ is listed in Figures 4 and 6.

\section{Hauterivian Open-marine Environments (Unit VIII, Cores 143-866A-148R to -171R)}

Lithologic Unit VIII is represented by $220 \mathrm{~m}$ of oolitic and oncolytic limestones and shows extensive dolomitization at several thick levels (Fig. 4). Facies are monotonous, consisting of well-sorted oosparites (facies 2) and oo-oncosparites with rounded micritic oncoids (facies 4 ).

Four depositional sequences exist in this lower unit.

Depositional sequence 1 ( $35 \mathrm{~m}$ thick, $1589-1624 \mathrm{~m}$ below seafloor [msbf], Cores 143-866A-167R to -171R) represents a transgression above basaltic basement. At the bottom, a thinning-upward parasequence set consisting of shallowing-upward parasequences occur in which facies 1 grades up to facies 2 toward the top. Macrofauna is represented by corals and echinoderms. The top of this parasequence set, interpreted as a TST, is represented by a hardground covered by oysters. The maximum depth occurs within a thin layer of fine-grained peloidal grainstone (facies 1). Above, a dolomitized parasequence set is characterized by large oncoids that probably represents facies 4 .

Depositional sequence 2 (68 m thick, 1521-1589 msbf, Cores 143-866A-160R to -167R) shows, from the bottom to the top: (1) a set of two parasequences, the second corresponding to a deepeningupward sequence (facies 4 at the base and facies 2 at the top) with the presence of some corals and the progressive disappearance of oncoids toward the top; (2) a maximum water depth corresponds to a thin peloidal and oolitic grainstone; (3) a thick parasequence set, with several levels of extensive dolomitization. Facies 4 is characterized predominantly by large rounded oncoids, especially in the dolomitized layers.

Depositional sequence 3 (71 m thick, $1450-1521 \mathrm{msbf}$, Cores $143-866 \mathrm{~A}-153 \mathrm{R}$ to $-160 \mathrm{R}$ ) is characterized by extensive development of facies 4 , which is monotonous in character, as observed both in cores and logs (Fig. 4). The bottom parasequences are dolomitized, and at the top, they are capped by hardgrounds, the last of which are covered by Arctostreon oysters. Core 143-866A-167R, is marked by the presence of Arctostreon, which live generally on hardgrounds in a water depth of a few tens of meters and are typical of more deep open-marine environments (deep subtidal depositional environments). This layer is overlain by massive, thick parasequences of facies 4 .

Depositional sequence 4 (46 m thick, 1404-1450 msbf, Cores $143-866 \mathrm{~A}-148 \mathrm{R}$ to $-153 \mathrm{R}$ ) is characterized by the development of facies 2 (oolitic grainstone). The basal sequence boundary is not obvious owing to the extensive dolomitization that occurs from Cores $143-866$ A-155R to $143-866$ A-163R. Possible boundaries are the basal part or the top of this dolomitized level. The first part is represented by facies 1 and 2 parasequences, commonly capped by hardgrounds with bivalves boring. Large rounded oncoids decrease in number and size from the bottom to the top and disappears just below a peloidal fine-grained grainstone layer that represents a deeper depositional environment. Upward, aggrading parasequences (facies 1 and 2) typical of beach deposits occur, and these generally are capped by early cementation layers. Corals and echinoderm plates disappear progressively upward, showing the decrease in open-marine conditions that developed at the top of depositional sequence 4 .

The four depositional sequences of the Unit VIII interval are characterized by (1) the predominance of oolitic and oolitic-oncoidal grainstones (facies 2 and 4), (2) cyclic sedimentation, and (3) dolomitization. 
Large-scale cyclicity results from the predominance of facies 2 oolitic grainstones at the bottom (depositional sequence 1) and at the top (depositional sequence 4) and facies 4 oolitic oncolytic grainstone-packstone in the middle part. This general evolution corresponds to (1) basal transgression above the basaltic island (volcanic clasts exist from Cores 143-866A-171 to -165R), (2) development of shallow open-marine and quiet environments with sedimentation rates that are of the same order as the subsidence rates, and (3) progressive deepening of the environments at the top of the interval, probably owing to a subsidence rate increase and/or sea-level rise (eustatic influence).

The paleogeography is unknown, but probably corresponds to a shoal that surrounded a small volcanic island only during the first stage of carbonate platform development. Beach and oolitic bars were well developed, but there is no evidence for reefs or tidal flats.

\section{Hauterivian-Barremian Restricted Shallow Subtidal to Supratidal Environments (Subunit VIC pro parte and Unit VII, Cores 143-866A-148R to-103R)}

This 440-m-thick series consists of limestones deposited in the most restricted shallow subtidal to supratidal environments that were observed in Hole 866A (Fig. 4). Sabkha deposits, algal-microbial mats, and mudstone-wackestone bearing ostracodes and small benthic foraminifers are predominant. Transgressive facies (wackestonepackstone with blackened elements) that contain few corals or hydrozoan colonies occur. The most significant of these correspond to a coarse-grained grainstone with rudist clasts or oolitic grainstones. Massive dolomitization occurs from Cores 143-866A-132R to-135R. Discrete dolomitization also exists in several cores, generally linked with algal-microbial mats.

Depositional sequence 5 (41 m thick, 1363-1404 mbsf, Cores 143-866A-144R to $-148 \mathrm{R}$ ) has a sequence boundary (Sb5) (Core 143-866A-148R, $1404 \mathrm{msbf}$ ) that is the most impressive one in Hole $866 \mathrm{~A}$. It corresponds to a brecciated level with reworked pebbles, which corresponds to an emersion level at the top of the underlying oolitic shoal. Depositional sequence 5 begins with a well-developed parasequence set (from Cores 143-866A-145R to -148R) that shows general aggradation (interpreted as a keep-up, Jacquin et al., 1991), characterized by restricted shallow subtidal to intertidal environments, at the bottom, and a deepening of the depositional environment to the top (interpreted as a give-up, Jacquin et al., 1991), where the environment grades from restricted to open-marine shallow subtidal. Facies with small benthic foraminifers, bird's eyes, and oncolites are well developed in the basal part, and facies with green algae and gastropods occur at the top. Small algal-microbial mat levels exist at the bottom, but disappear progressively toward the top. Subaerial exposure, with desiccation cracks and well-cemented levels, occurs at the top of transgressive parasequences. Thin dolomitic levels exist. A packstone-grainstone level with echinoderm plates, small benthic foraminifers, and reworked ooids corresponds to the deeper depositional environments. At the top, the 6-m-thin series is represented only by two or three parasequences, which are characterized by restricted shallow subtidal to intertidal environments (algal-microbial mats) and exposure surface (paleosoils).

Depositional sequence 6 (60 m thick, 1303-1363 msbf, Cores 143-866A-138R to -144R) has a sequence boundary (Sb6) placed at the top of a dolomitic bed that corresponds to the last sequence 5 parasequence and is overlain by coarse-grained grainstone. Dolomitization below a sequence boundary is also observed in some eastern Tethys Urgonian platforms (Arnaud and Lemoine, 1993). The overlying 20-m-thick succession contains interbedded oolitic grainstone and coarse-grained grainstone-rudstone with rudist and gastropod clasts, the latter interpreted as tempestites might represent the next TST. Corals and hydrozoans are abundant. The facies distribution and fauna indicate subtidal open-marine environments at the bottom indicating a flooding. Thus, this parasequence set is interpreted as a late TST. The deepest depositional environment is represented by a less-sorted peloidal packstone with reworked ooids and bowl-shaped coral colonies. This layer, might be the record of the mfs. The basal HST surface corresponds to a sharp lithologic boundary, interpreted as a possible downlap surface. An early highstand (Cores 143-866A-142R to-139R) corresponds to thick aggrading parasequences deposited in open-marine shallow subtidal environments. Facies are represented by wackestonepackstone with rudists, gastropods, small benthic foraminifers, and echinoderm plates. Coarse-grained grainstone (tempestites?) may exist according to the logs, but they were not recovered. At the top, the last, thin parasequences consist of bird's-eye facies, algal-microbial mats, and subaerial exposure with desiccation cracks, showing the appearance of restricted shallow marine environments and emersions.

Depositional sequence 7 (26 m thick, 1277-1303 msbf, Cores $143-866 \mathrm{~A}-135 \mathrm{R}$ to $-138 \mathrm{R}$ ) is characterized by intense dolomitization at the bottom. The dolomitic level (1292-1302 mbsf) contains bivalves and echinoids that correspond to open-marine environments lying just above the restricted shallow subtidal environment at the top of depositional sequence 6 . According to this interpretation, the dolomitic level may correspond to bioclastic grainstones deposited just above the sequence boundary Sb7. The deepest depositional environment is placed at the top of this dolomitic level based on the presence of large echinoid fragments. Above, thick parasequences deposited into open-marine to slightly restricted shallow subtidal environments consist of wackestones with caprinid rudists and gastropods, mudstone-wackestone with Istriloculina, and oncoidal wackestone-packstone. Reworked ooids are frequent at the base of this last parasequence set.

Depositional sequence 8 (56 m thick, 1277-1336 mbsf, Cores $143-866 \mathrm{~A}-131 \mathrm{R}$ to $-135 \mathrm{R}$ ) is characterized by a 28 -m-thick layer of massive white dolomite (upper part of Subunit VIIB) containing few echinoderm plates and possible recrystallized corals. As for depositional sequence 7, this dolomitic level corresponds to secondary dolomitized coarse-grained grainstones deposited in open-marine shallow subtidal environments. The deepest depositional environment is probably located in Core 143-866A-133R for two reasons: interpretation of the gamma-ray log record (high gamma-ray value) and the presence of well-preserved echinoids that characterize subtidal open marine environment. Above, dolomitization become less important and thick parasequences that are typical and similar to that of the northeastern Tethys Urgonian platform (Arnaud-Vanneau and Arnaud, 1990) occur: (from bottom to top) rudist limestone, oncoidal limestone, and algal-microbial mats that are generally well developed in Hole 866A. Bird's eyes are frequent in oncoidal facies and algal-microbial mats. These shallowing-upward parasequences were deposited in slightly restricted shallow subtidal environments that grade upward to restricted intertidal environments.

Depositional sequence 9 ( $22 \mathrm{~m}$ thick, 1208-1230 mbsf, Cores 143-866A-128R to -130R) has a facies type similar to depositional sequences 8 and 9 . Two different possibilities exist for the sequence boundary: the first one is in Core 143-866A-131R, where more openmarine facies lie above restricted marine facies, and the second one is in Core 143-866 A-130R, where the sequence boundary may correspond to the top of a dolomitic level. At the bottom, the first parasequences are topped by algal-microbial mat or oncoidal levels, whereas the last parasequences have gastropods and rudists that characterize more open-marine environments. Above, Core 143-866A$129 \mathrm{R}$ lith- ologies include an oolitic packstone-grainstone layer with reworked ooids, which is interpreted as the deepest and higher energy environment. This layer is overlain by a clear lithologic boundary, interpreted as a downlap surface. The last parasequence set of sequence 9 includes thin parasequences characterized by well-developed oncoidal facies and the disappearance of algal-microbial mats.

Depositional sequence 10 (68 m thick, 1140-1208 mbsf, Cores $143-866 \mathrm{~A}-121 \mathrm{R}$ to $-128 \mathrm{R}$ ) has a sequence boundary that is proposed to be at the top of a dolomitic bed, above which reworked ooids and blackened elements appear. The 30 -m-thick basal parasequence set can be divided into two parts. The lowest one includes several 


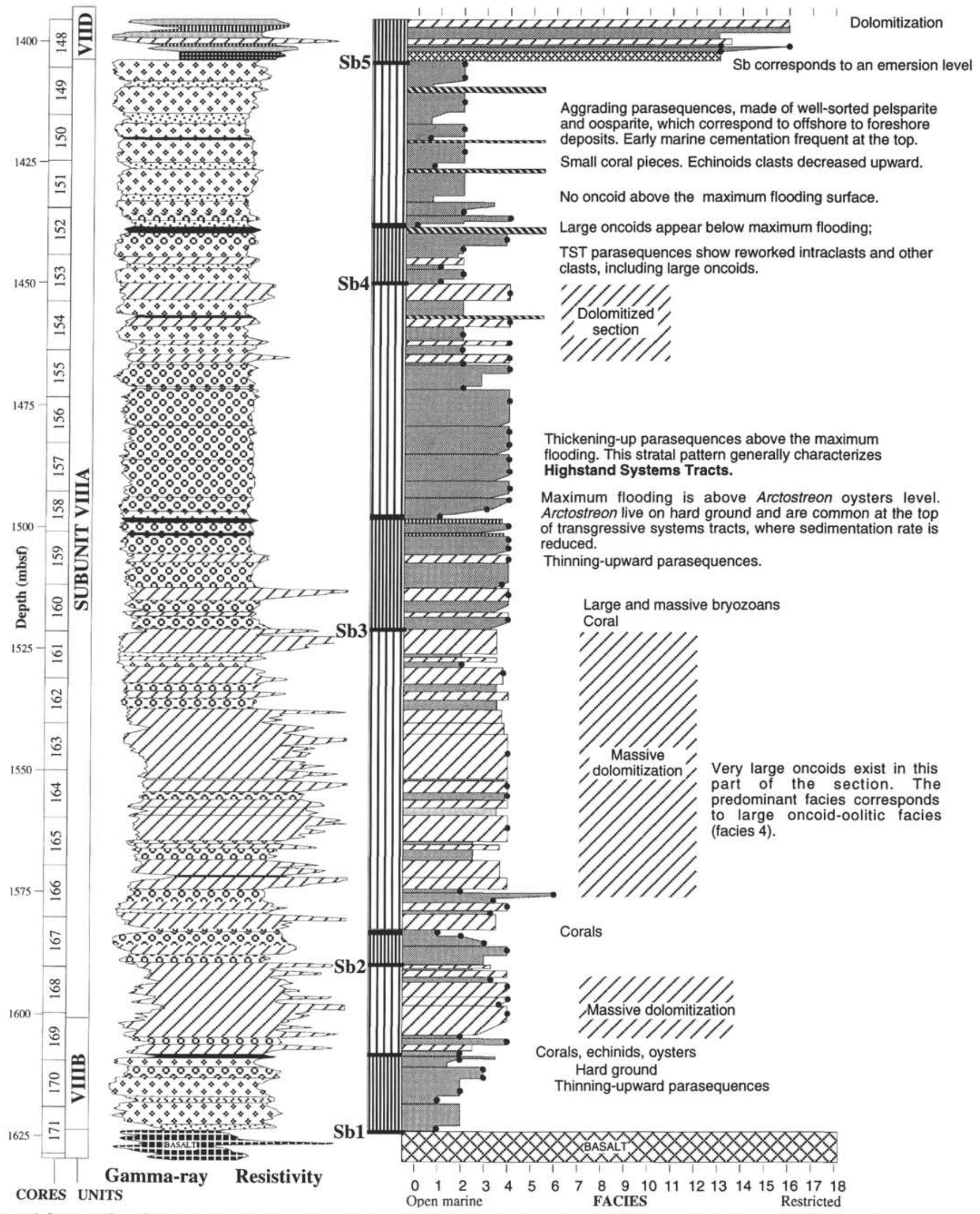

Figure 4. Interpretation of physical logs and the vertical evolution of facies and sequence stratigraphy (Cores 143-866A-171R to -47R). Lithologic units after Sager, Winterer, Firth, et al. (1993). Black circles correspond to the probable location of some of the studied samples. 


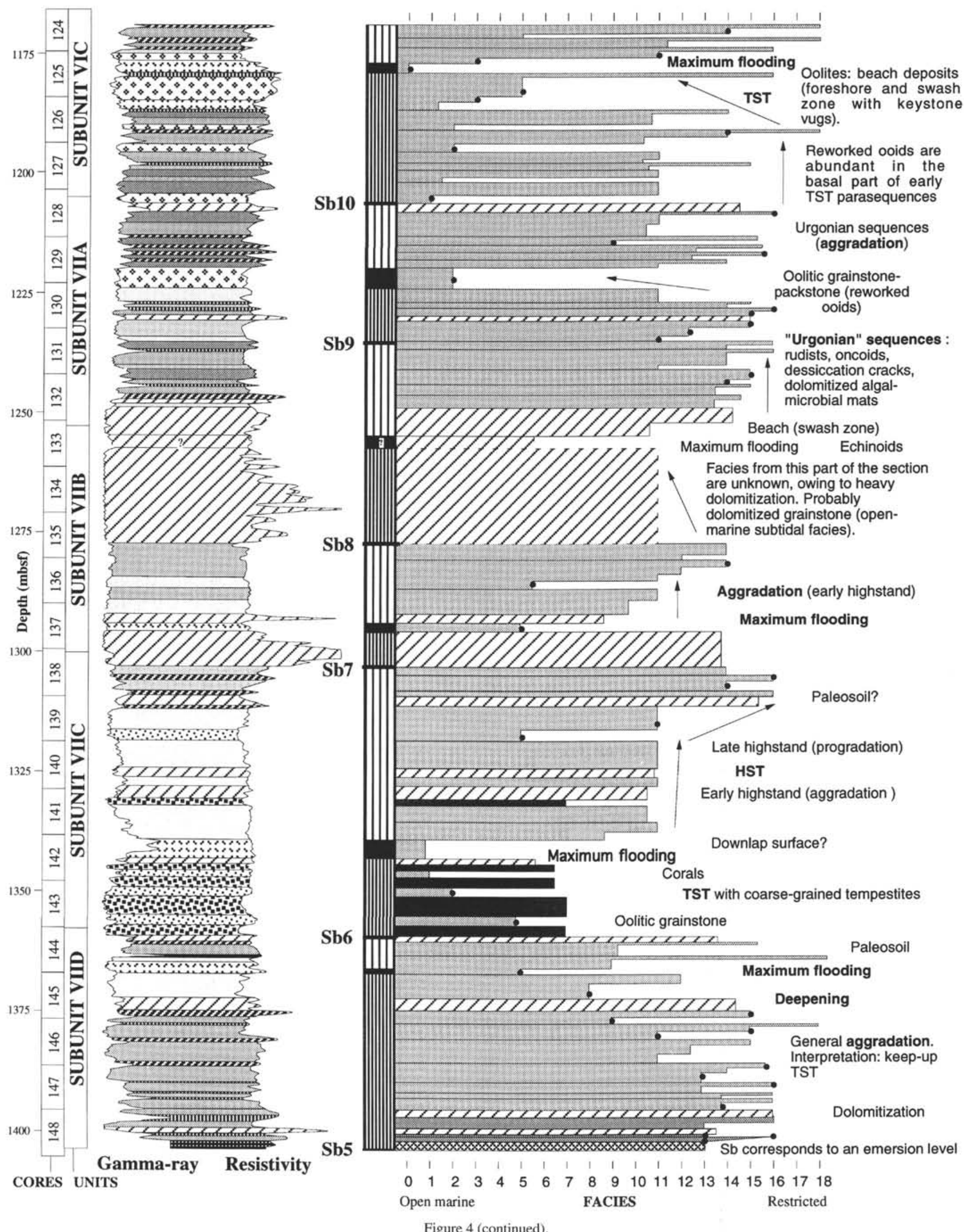

Figure 4 (continued). 


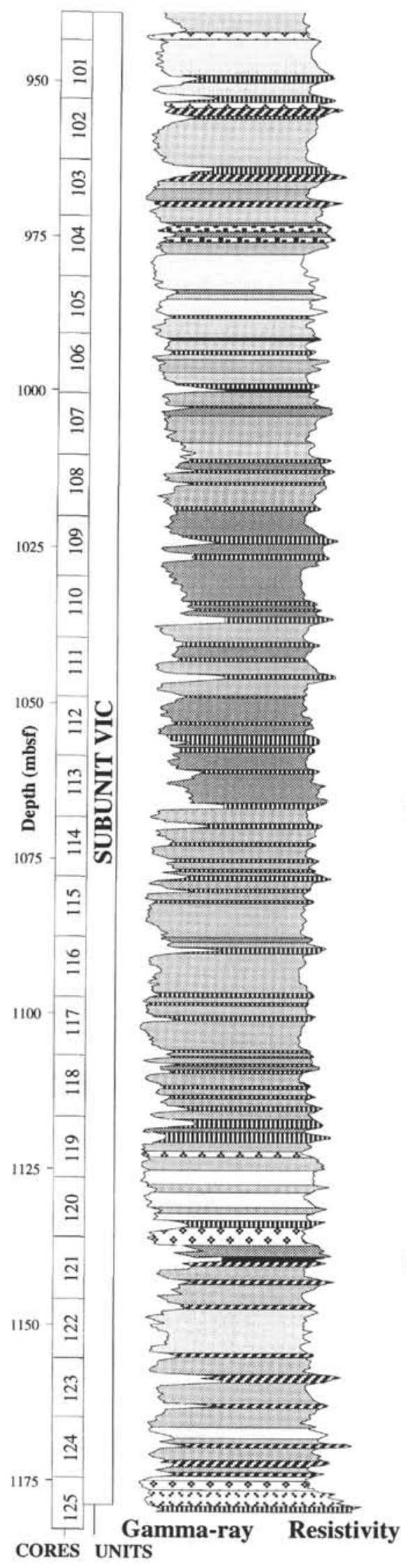

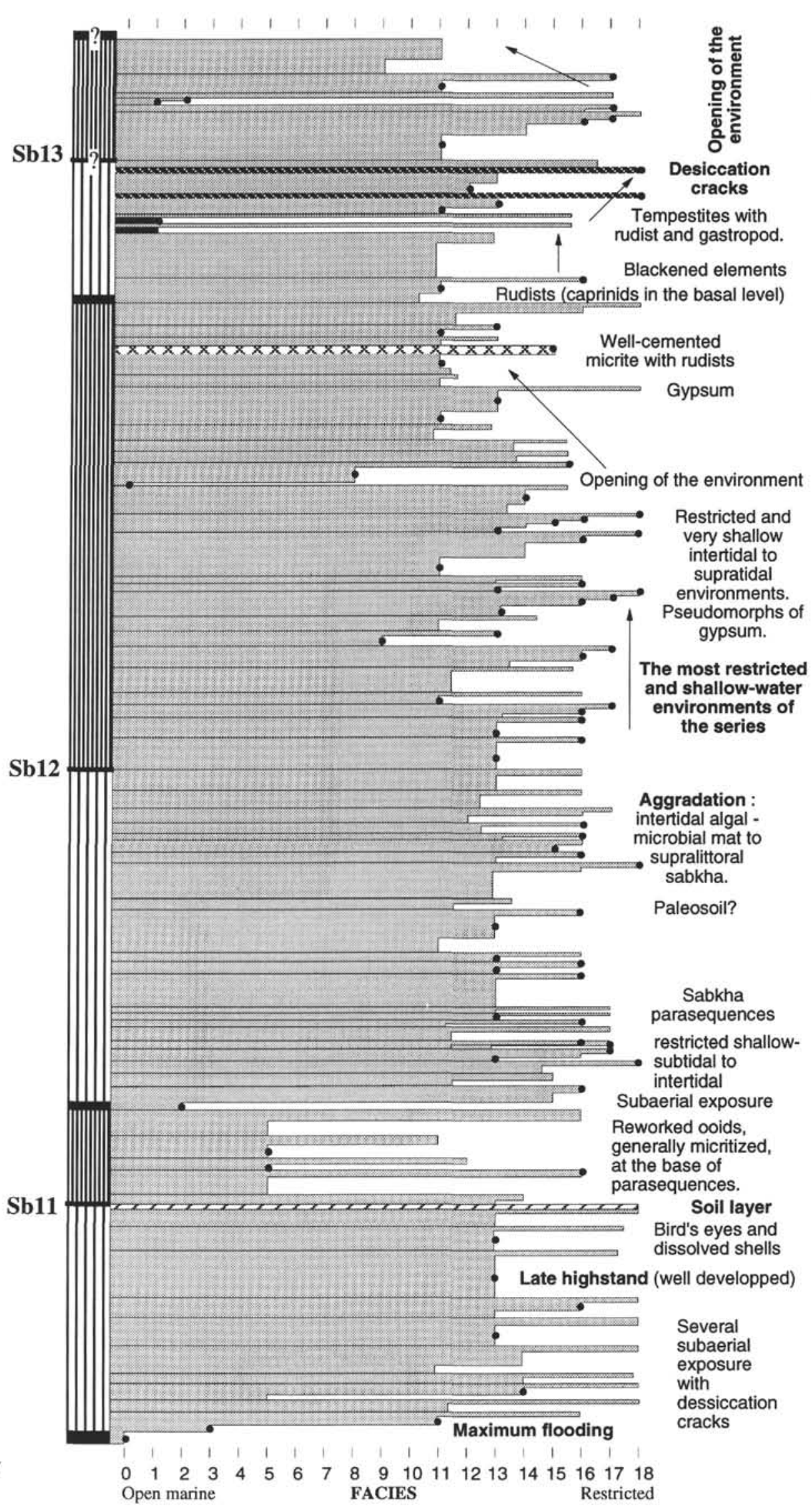

Figure 4 (continued). 


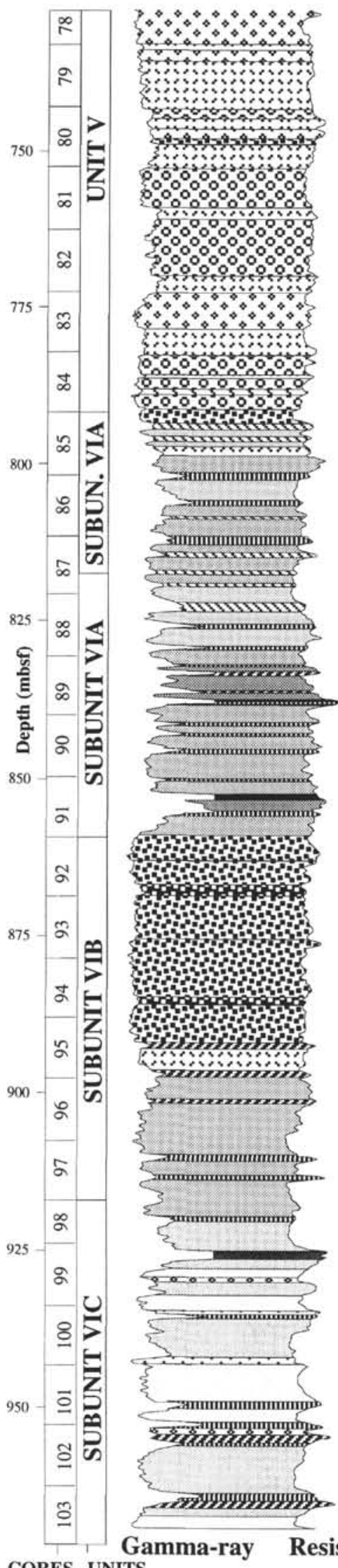

CORES UNITS

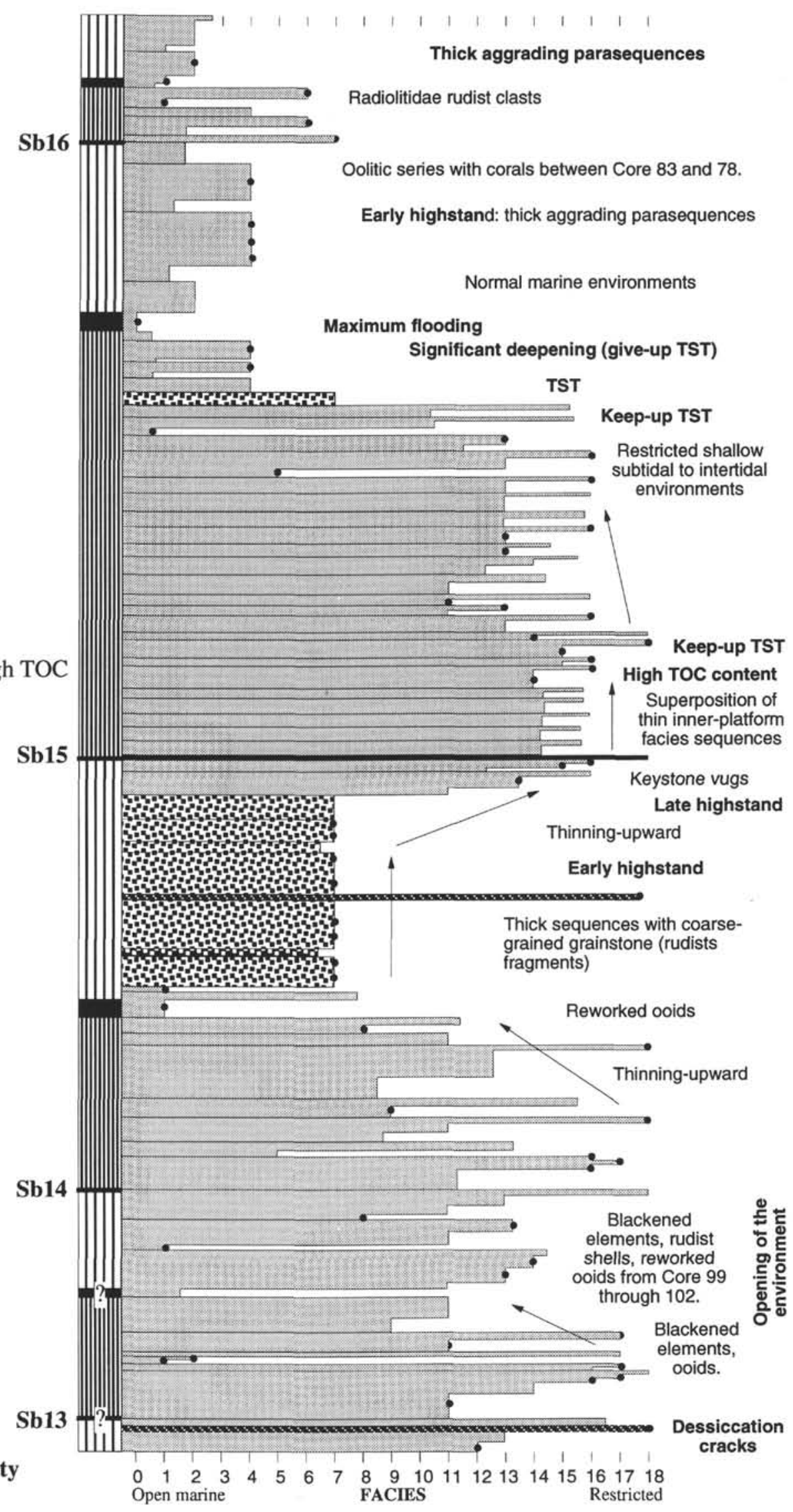

Figure 4 (continued). 


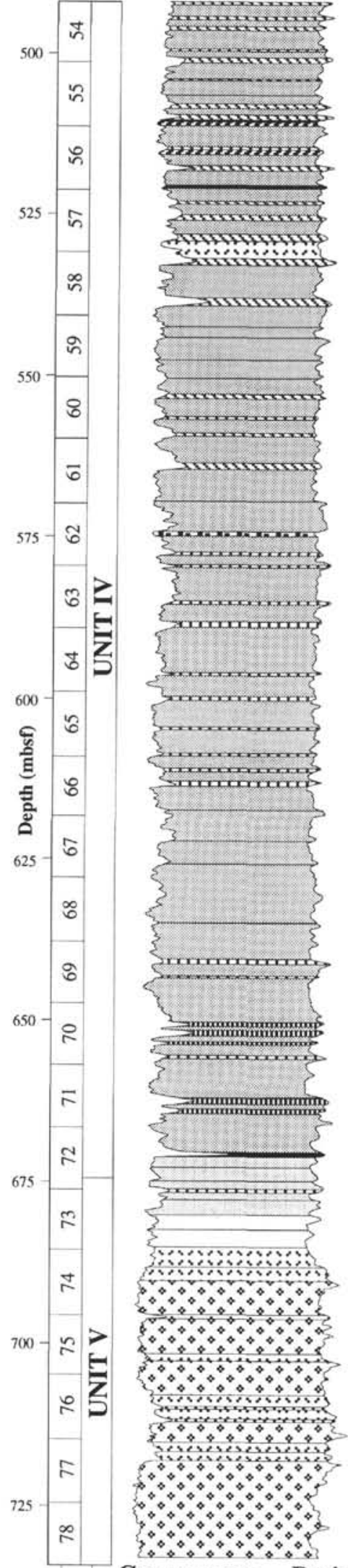

Gamma-ray Resistivity CORES UNITS
Sb19

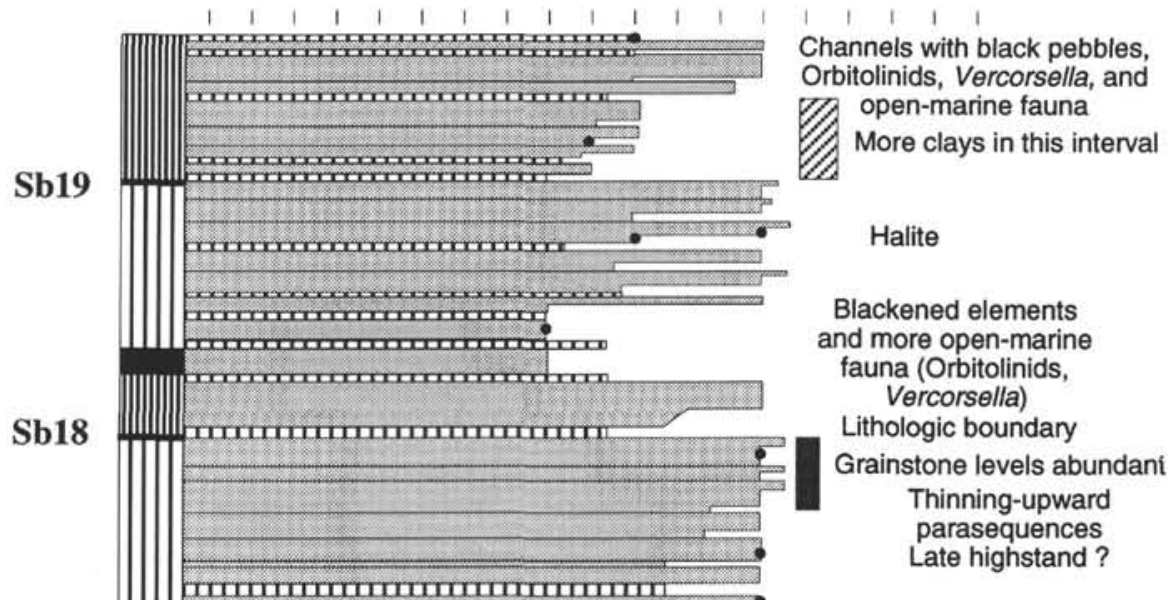

Early highstand possible (thick aggrading

parasequences)

Possible tempestite

Sb17

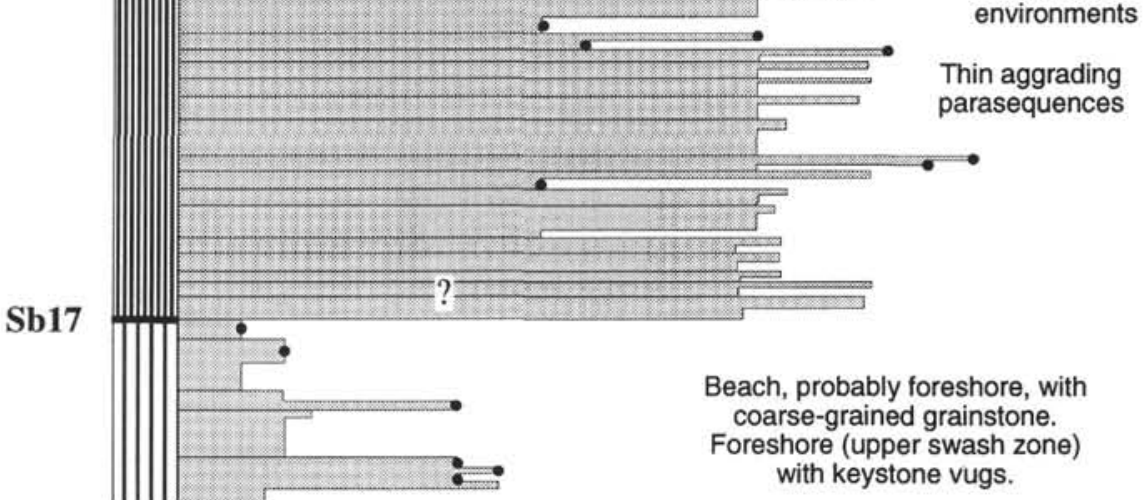

Deepening -

upward

sequences

Shallow subtidal and restricted marine environments

HST
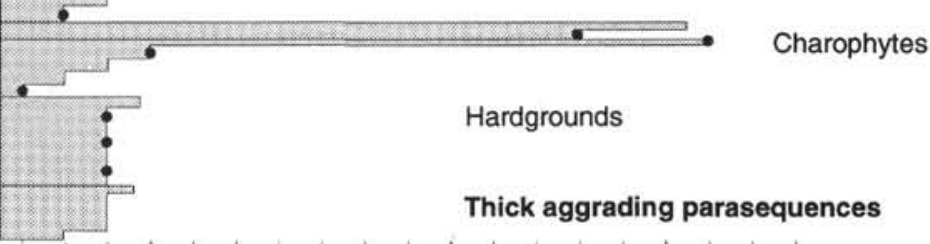

Hardgrounds

Thick aggrading parasequences

$\begin{array}{lllllllllllllllllll}0 & 1 & 2 & 3 & 4 & 5 & 6 & 7 & 8 & 9 & 10 & 11 & 12 & 13 & 14 & 15 & 16 & 17 & 18\end{array}$ Open marine FACIES Restricted

Figure 4 (continued). 


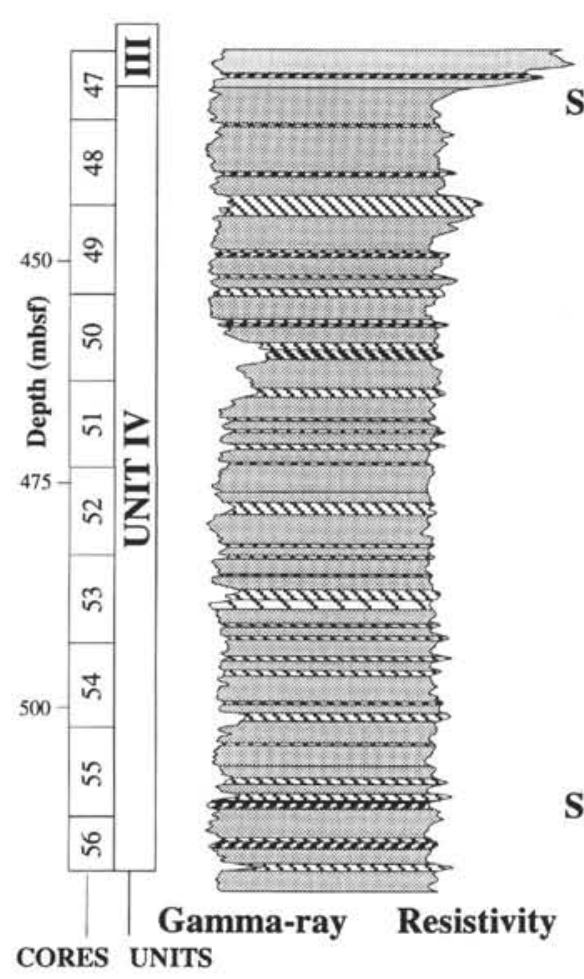

LOG INTERPRETATION

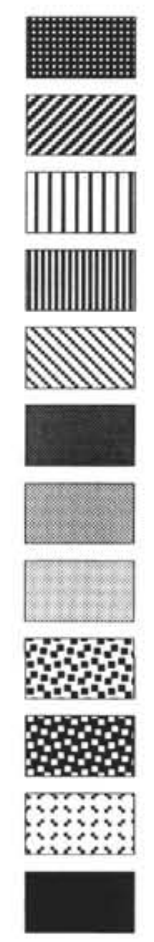

\section{Paleosoil}

Well-lithified mudstone-wackestone with dessiccation cracks

Thin-bedded, organic-rich layers and algal mats

Algal-microbial mats

Clayey wackestone-packstone

Mudstone-wackestone with bird's eyes, oncolites small foraminifers and ostracodes

Wackestone-packstone with gastropods, and/or rudists, or Cayeuxia

Coarse-grained grainstone

Coarse-grained wackestone-packstone

Peloidal and oolitic wackestone-packstone

Hardgrounds
Wackestone-packstone with

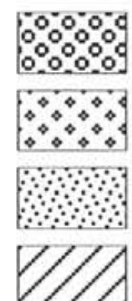

Oolitic and oncoidal packstone-grainstone

Well-sorted oolitic grainstone

Fine-grained grainstone-packstone

with reworked oolites

Dolomitization

Volcanic basement

\section{SEQUENCE STRATIGRAPHY}

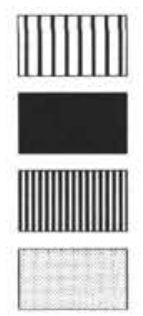

Highstand systems tract

Maximum flooding

Transgressive systems tract

Lowstand systems tract

Figure 4 (continued).

parasequences characterized by slightly restricted shallow subtidal deposits with reworked ooids and blackened elements. The upper part shows parasequences with increasing amounts of ooids. Grainstone with keystone vugs (swash zone) are common. Some of these parasequences are capped by subaerial exposure horizons having desiccation cracks. Above, oolitic and peloidal packstones-grainstones containing various and abundant small benthic foraminifers correspond to subtidal open-marine environments. The 36-m-thick last parasequence set indicates slightly restricted shallow subtidal environments, but subaerial exposure occurs generally at the top of the parasequences. The first parasequences contain an oolitic grainstonepackstone with keystone vugs, and the uppermost parasequences are characterized by wackestone-packstone bearing rudists clasts and gastropods, interpreted as deposited in more restricted environments. 
From the bottom to the top, the parasequences appear to be topped by a subaerial exposure layer with desiccation cracks. These layers generally result from the emersion of mudstone wackestone with ostracodes or bird's eyes deposited in restricted shallow subtidal to intertidal environments. This feature could be linked with small-scale, regular cyclic variations of relative sea level (alternation of submersions, and emersions). These well-cemented subaerial exposure layers display a characteristic log signature (high gamma-ray and resistivity values).

Depositional sequence 11 (73 m thick, 1067-1140 msbf, Cores $143-866 \mathrm{~A}-113 \mathrm{R}$ to $-121 \mathrm{R}$ ) has a sequence boundary (Sb11) marked by the presence of a reddish brown soil overlying a dolomitic crust that probably resulted from pedogenetic effects and freshwater circulation. Depositional sequence 11 is characterized by extensive, very shallow and restricted subtidal to supratidal environments. The 16-m-thick transgressive facies is distinguished at the bottom. It is characterized by less-restricted shallow subtidal environments where reworked ooids are abundant. Dominant facies correspond to wackestone-packstone with bird's eyes or gastropods; algal-microbial mats are less abundant. A thin oolitic level, with reworked and micritized ooids, occurs in Core 143-866A-119R (Fig. 4) and is interpreted as the most open-marine depositional environment. Up to the top, a thick parasequence set consists of predominant sabkha sequences and algal-microbial mat layers. In each parasequence, environments grade upward from restricted shallow subtidal (wackestones with ostracodes and/or small gastropods) to intertidal (algal-microbial mats) and supratidal environments (mudstone-wackestone with thin sedimentary laminations and organic layers). These tidal flat and sabkha intervals were probably located near an island covered by vegetation because land-plantderived vitrinite was found in Core 143-866A-118 (Baudin et al., this volume). As in depositional sequence 10 , the cyclic distribution of the facies could be linked to cyclic variations of relative sea level during a period of similar sedimentation and subsidence rates.

Depositional sequence 12 (103 m thick, 964-1067 msbf, Cores 143-866A-103R to -113R) does not have a well-established sequence boundary. Nevertheless, we propose to place the sequence boundary Sb12 in Core 143-866A-113R for two reasons: (1) the presence of a very high gamma-ray interval, which is interpreted as a reworked layer above the transgressive surface, and (2) the appearance of blackened elements in the upper part of the core. As for depositional sequence 11, sequence 12 is characterized by significant subsidence, a high rate of sedimentation, and a very well developed small-scale cyclicity. The basal part of sequence 12 is very thick $(79 \mathrm{~m})$. It shows clearly two different intervals: the lowest one, from Cores 143-866A-113R to $-109 R$, and the second one, from Cores 143-866A-108R to -105R. The lower interval is an aggrading parasequence set in which the facies correspond to deposition in the most restricted environments of all of the Hole $866 \mathrm{~A}$ sequences. Algal-microbial mats, stromatolites, flatpebble layers, mudstone-wackestone with bird's eyes, mudstone-wackestone with ostracodes, and Istriloculina are predominant. Pseudomorphs of gypsum crystals (Core 143-866A-109R) and several subaerial exposition surface having desiccation cracks were observed, as well as the occurrence of land-plant-derived vitrinite (Core 143-866A110 , Baudin et al., this volume). The less-restricted environments are represented by a wackestone-packstone with gastropods. In these very restricted shallow subtidal to supratidal environments, blackened elements and Thalassinoides burrows characterize the transgressive conditions. The upper interval is marked by an progressive opening of environments with (1) the progressive disappearance of algal-microbial mats and layers with thin dark laminations, (2) presence of transgressive facies, (3) appearance of reworked micritized ooids, and (4) appearance and increase of bivalve clasts (including rudists), green algae, and small benthic foraminifers. Facies corresponding to more restricted environments exist also, such as mudstone-wackestone with bird's eyes, oncolites, and possible pseudomorphs of gypsum or anhydrite. In the uppermost part, channels may have existed, with thin marly intervals (Cores 143-866A-106R and -107R).
Open-marine conditions in Core 143-866A-105R are represented by a layer with rudists (including Caprinidae) and large gastropods deposited in open-marine shallow subtidal environments (Aptian caprinids are well known to live only in open-marine water; Masse, 1976).

The upper, 22-m-thick series consists of a thinning-upward parasequence set, with basal aggradation followed by progradation, where facies are representative of open-marine to slightly restricted shallow subtidal environments. Wackestones or wackestones-packstones with rudists, gastropods, green algae, small benthic foraminifers, and reworked ooids are predominant. In the lowest parasequences, thin grainstone layers with graded-bedding are interpreted as tempestites. In the upper parasequences, well-cemented layers with desiccation cracks show that the emersion level was reached, but without the development of intertidal to supratidal environments (tidal flats).

In conclusion, this 440-m-thick unit consists of eight depositional sequences, the thicknesses of which decrease from the bottom to Sb10 and then increase to the top. The most highly restricted environments observed in Hole 866A occur in sequence 12. Two parts are distinguished, the limit of which corresponds approximately to an important physical-property boundary (Sager, Winterer, Firth, et al., 1993): the lower part (sequences 5 through 9 ) is characterized by an important deepening of environments and the appearance of open-marine conditions in sequences 6 and 8; the upper part (sequences 10 through 12) is characterized by the most restricted environments. Algal-microbial mats and intertidal to supratidal deposits are predominant in this interval. However, algal-microbial mats layers are present or are more developed in the basal part, with a general decrease toward the top, whereas subaerial exposure intervals with well-lithified beds and desiccation cracks are more abundant in the upper part of the depositional sequences. Dolomitization is less important than in the Hauterivian series and disappears upward. Except for the sequence 8 massive dolomitization of previously open-marine grainstones, the most important dolomitic interval seems to be linked with sequence boundaries. Generally, cyclic variations of relative sea-level are not of the same scale from one depositional sequence to another. Two cases can be distinguished, with all intermediate situations. In the first case (for example, sequences 5 and 6), the variations of relative sea-level are significant with the maximum flooding sea-level of the second sequence higher than the first one: the general arrangement of the two sequences is transgressive but the fall of relative sea-level, linked with sequence boundary Sb6, is so significant that the late transgressive open-marine parasequences of sequence 6 directly overlie early highstand parasequences of the underlying sequence 5. Clearly, the general transgressive tendency observed masks an important break of sedimentation. In the second case (for example, sequences 11 and 12), the general arrangement is regressive, with the sequence 12 maximum flooding relative sea-level lower than the sequence 11 maximum flooding, and the depositional environments of the first more restricted than those of the second. Second-order cyclicity can be identified for the relative sea-level variations in this third-order depositional sequence set.

\section{Aptian Transgressions (Unit V and Subunits VIA, VIB, and VIC pro parte, Cores 143-866A-73R to -103R)}

This 280-m-thick series corresponds to a general opening of the environments and records the presence of two transgressions. They are correlated with the Aptian second-order transgression and characterized by the development of open-marine shallow subtidal sedimentation (Fig. 4). After the Barremian highly restricted environments, the "Aptian transgression" began with depositional sequence 13, with the maximum deepening reached with depositional sequence 15 .

Depositional sequence 13 (38 m thick, 926-964 mbsf, Cores $143-866 \mathrm{~A}-99 \mathrm{R}$ to $-103 \mathrm{R}$ ) is marked by a general opening of the environments after the restricted marine conditions of deposition of sequences 11 and 12. Sequence boundary $\mathrm{Sb} 13$ is placed at a high 
gamma-ray and resistivity layer. From the base to the top of the basal parasequence set, there is evidence of deepening of water characterized by (1) the disappearance toward the top of tidal flat environments (algal-microbial mats or sabkhas), (2) appearance of blackened elements and reworked ooids, and (3) increase in rudists, gastropods, green algae, and benthic foraminifers. Wackestone with bird's eyes, layers with desiccation cracks, and pseudomorphs of gypsum occur in Core 143-866A-102R, but wackestones with rudists and gastropods are more abundant higher in the section. The top of this interval consists of an oolitic grainstone layer (lowest part of Core 143-866A100R) deposited in shallow subtidal open marine environment.

The upper parasequence set consists of thick aggrading parasequences. Facies are mainly wackestones and wackestones-packstones with rudist clasts, gastropods, and benthic foraminifers, and correspond to shallow subtidal open marine to slightly restricted environments. Oyster clasts, blackened elements, Thalassinoides burrows, and reworked ooids disappear progressively toward the top.

Depositional sequence 14 (73 m thick, 853-926 msbf, Cores 143-866A-91R to $-99 \mathrm{R}$ ) has a proposed sequence boundary located in Core 143-866A-99R, between the sequence 13 and the overlying, more restricted environments belonging to sequence 14. Pseudomorphs of gypsum are possible according to the shipboard visual core description, but they were not found in our samples.

The basal parasequence set shows more restricted environments than in the underlying sequence 13. Facies are algal-microbial mats, flatpebble layers, thin dark sedimentary laminae, and mudstonewackestone with bird's eyes (Cores 143-866A-97R and -98R). Upward, the environments became less restricted, according to the following observations: (1) progressive disappearance of algal-microbial mats and adjacent facies, (2) development of rudist and gastropod facies, (3) appearance of reworked ooids, and (4) presence of transgressive facies with abundant benthic foraminifers and, in Core 143866A-96R, Palaxius microcoprolites. Mudstone-wackestone layers with ostracodes and Istriloculina occur also, and desiccation cracks exist in some of them (Cores 143-866A-96R and -97R). The top of this interval shows a peloidal and oolitic level located in Core 143-866A$95 \mathrm{R}$ that corresponds to a deeper depositional environment.

Two parts are distinguished in the following 40-m-thick parasequence set. The first one aggrading (Cores 143-866A-93R to-95R), without vertical change of facies, and the second one prograding (Cores 143-866A-91R to -93R) and showing a shallowing-upward trend of facies. The basal part includes several thick parasequences, the first of which contains a coarse-grained grainstone-rudstone with large rudist fragments (including caprinids) and shell fragments lying parallel to bedding and current oriented. Benthic foraminifers are missing because of sorting by currents. According to the logs, finegrained grainstone or packstone may also occur in these parasequences, which are interpreted as tempestites or deposits made in turbulent open-marine water above the fair-weather wavebase. Toward the top, the sediments grade to a peloidal wackestone-packstone with rudist clasts, including caprinids (open-marine shallow subtidal environments). The upper part is characterized at the base by packstones with rudist clasts and gastropods (including nerineids) with green algae and with oncoids (Bacinella), whereas wackestonespackstones with bird's eyes and algal-microbial mats appear at the top. Thus, the environments grade upward from open-marine shallow subtidal to restricted shallow subtidal and intertidal. The tops of the parasequences are characterized by erosional surfaces (Core 143866A-91R). Beach level (grainstone with keystone vugs) also occurs in Core 143-866A-91R.

Depositional sequence 15 (103 m thick, 750-853 mbsf, Cores 143 $866 \mathrm{~A}-80 \mathrm{R}$ to $-91 \mathrm{R}$ ) has a sequence boundary that corresponds to a high-gamma-ray layer in Core 143-866A-91R between the thinningupward parasequence set of the underlaying sequence 14 and the thick aggrading parasequence set of the overlying sequence 15 .

The basal 72-m-thick parasequence set can be divided in two parts, the first (52-m-thick) made of a thick aggrading parasequence set and the second by thickening-upward parasequences ( 20 -m-thick). The lower part (Cores 143-866A-86R to -91R) corresponds to the superposition of numerous thin parasequences, which were deposited in restricted shallow subtidal to intertidal environments. Algal-microbial mats and flat-pebble layers, wackestones-packstones with bird's eyes, and desiccation cracks are predominant. Wackestones-packstones with gastropods and rudist clasts are minor components. Transgressive conditions are well documented by (1) the presence of blackened peloids and bioclasts as low in the sequence as Core 143-866A-89R, (2) presence of a layer rich in Terquemella green algae in Core 143-866A-89R and Gervillia bivalves in Core 143-866A-88R, and (3) occurrence of Thalassinoides burrows. This lower part is also characterized by the abundance of admixed volcanic debris and volcanic glasses (Cores $143-866 \mathrm{~A}-89 \mathrm{R}$ to $-87 \mathrm{R}$ ). Cuticles and coal fragments with microcracks are abundant in Core 143-866A-86R. The more pronounced variation in total organic carbon (TOC) content was observed in interval 143-866A-89R-1, 92-100 cm. Organic content varies between $0.47 \%$ and $14.38 \%$ and Sample $143-866$ A-89R-1, $98-99 \mathrm{~cm}$, shows the occurrence of land-plant-derived vitrinite (Baudin et al., this volume). This indicates that, at this time, Resolution Guyot clearly was a small, flat island covered by vegetation and surrounded by a welldeveloped tidal flat as far as the shelf break. Small cyclic variations of relative sea level explain the sporadic opening of the environment with the deposition of sandy muds bearing benthic foraminifers, rudists clasts, gastropods, and green algae. Autochtonous marine organic matter is significant in Sample 143-866A-86R-2, 111-113 cm (Baudin et al., this volume), indicating that the island was becoming progressively submerged. An important opening of the environments occurs in Cores $143-866 \mathrm{~A}-83 \mathrm{R}$ to $-85 \mathrm{R}$, in which the restricted shallow subtidal and intertidal environment (Core 143-866A-86) change to open-marine subtidal (Core 143-866A-84R). This change is marked by the disappearance of algal-microbial mats and intertidal deposits, the disappearance of reworked oolites and their replacement by autochtonous oolitic grainstones, major increase of benthic foraminifers, and appearance of abundant echinoderm plates, including crinoids. A wackestone-packstone with rudist clasts and gastropods and thin algal mat layers exist in Cores 143-866A-86R and -85R, but peloidal-oolitic packstones and oolitic grainstones with large rounded oncoids are predominant in Core $143-866 \mathrm{~A}-84 \mathrm{R}$ and above. In some cases, the top of the oolitic parasequences corresponds to hardgrounds bored by bivalves. At the top of this interval, a layer with various corals occurs in Core 143-866A-83R and corresponds to shallow subtidal open-marine environments.

The upper parasequence set, almost $30 \mathrm{~m}$ thick, corresponds to thick parasequences in which oolitic grainstones are the dominant lithology.

Depositional sequence 16 (70 m thick, 680-750 mbsf, Cores $143-866 \mathrm{~A}-73 \mathrm{R}$ to $-80 \mathrm{R}$ ) has a sequence boundary that corresponds to a high-gamma-ray layer in Core 143-866A-80R.

The basal parasequence set consists mainly of oolitic grainstones. Corals are present (Cores 143-866A-80R to -78R), but open-marine shallow subtidal environments exist up to Core 143-866A-74R, where Gervillia and oyster clasts have been observed. Echinoderm plates (echinids and crinoids) and benthic foraminifers (including large forms such as Vercorsella) are abundant, but their number decrease toward the top. Rudist clasts are rare, but radiolitid debris was observed in Core 143-866A-79R. Owing to the fauna content, the maximum deepening appears to be in Core 143-866A-79R.

The upper parasequence set is a $40-\mathrm{m}$-thick unit. Oolitic grainstones are predominant at the bottom. Beach deposits (foreshore and swash zone with keystone vugs) are well developed in Cores 143$866 \mathrm{~A}-74 \mathrm{R}$ and $-75 \mathrm{R}$. Wackestone with ostracodes and charophytes occurs in Core 143-866A-76R. The uppermost part shows the appearance of wackestone-packstone with benthic foraminifers (especially miliolids), which corresponds to less open-marine and slightly restricted shallow subtidal environments. Most of this unit is interpreted as open marine, but less open-marine and slightly restricted shallow subtidal environments appear upward. 
The precise location of sequence boundary $\mathrm{Sb} 17$ in Cores 143$866 \mathrm{~A}-73 \mathrm{R}$ or $-72 \mathrm{R}$ pro parte cannot be indicated because of the poor recovery.

In conclusion, the 280-m-thick Aptian series corresponds to four depositional sequences, the thicknesses of which increase upward from sequence 13 to sequence 15 . Compared to the underlying series, the environments are less restricted and grade from slightly restricted to open marine. Thick successions deposited in open-marine subtidal environments characterize the sequence 14 and 15. Except for Unit VIII, these intervals correspond to the most open-marine deposits of Hole $866 \mathrm{~A}$. This feature probably resulted from the influence of high sea level worldwide during the Aptian transgressions (or world-wide reductions in carbonate production, Schlager, 1981). Nevertheless, the gradual sea-level rise varies from one depositional sequence to another: it began slowly in sequence 13 , where it is marked only by a general opening of the environment and the appearance of less restricted waters; sea-level rise is more significant in sequence 14, where rudist facies and coarse-grained grainstones interpreted as tempestites occur in shallow subtidal environments; and sea level reaches its highest level in sequences 15 and 16 with a thick succession of oolitic grainstones.

\section{Late Aptian-Albian(?) Regression (Unit IV, Cores 143-866A-48R through -73R)}

The upper Aptian-Albian interval is divided into three depositional sequences characterized by shallow subtidal environments, intertidal flats, and marshes (Fig. 4). Clays are commonly abundant. A major lithologic boundary is marked by the beginning of deposition of Unit IV. Despite the change from open-marine water (sequence 16) to more restricted subtidal-intertidal conditions, the basal deposits of Unit IV mark the first stage of the transgression and flooding of a previously exposed surface (Sager, Winterer, Firth, et al., 1993).

Depositional sequence 17 (141 m thick, 539-680 mbsf, Cores $143-866 \mathrm{~A}-58 \mathrm{R}$ to $-73 \mathrm{R}$ ) does not have a sequence boundary precisely located (see above). Two possible boundary locations exist: the first one in Core 143-866A-73R (as proposed in Fig. 4), and the second one in Core 143-866A-72R, below a clayey level that corresponds to the highest clay content in Hole $866 \mathrm{~A}(14.28 \%$, Baudin et al., this volume). Despite this problem, Sb16 is clearly linked with a sharp change in facies distribution because restricted-environment deposits overlie the more open-marine one of the underlying sequence 16.

The basal 105-m-thick parasequence set consists of numerous thickening-upward parasequences. Subtidal to intertidal environments grade from open-marine to slightly restricted, but are never as restricted as in the Barremian depositional sequences. Transgression conditions are marked by the existence of blackened elements from Core 143-866A72R upward, appearance of transgression facies in Core 143-866A-71R, abundance of bioturbation, and the presence of rare Orbitolinid large foraminifers observed in Core 143-866A-70R to -68R. On the other hand, echinoderm remnants are absent, because the environments were not completely open marine, but always slightly restricted. The lower part of this unit is characterized by wackestones-packstones with gastropods, green algae, and benthic foraminifers. Algal-microbial mats and flat pebbles are common in the lower part (Cores 143-866A-73R to -70R), but disappear progressively upward. Well-cemented mudstone with open burrows and layers with desiccation cracks occur in several layers. The upper part of the unit is characterized by deepening-upward parasequences showing, from the bottom to the top: (1) finely laminated organic-rich, with some clay, flaser-bedded wackestone; (2) burrowed calcareous wackestone-packstone; and (3) wackestone-packstone with gastropods and/or benthic foraminifers. The top of these parasequences usually corresponds to an irregular surface. Coaly fragments and organic matter in thin laminae or finely disseminated in the sediments occur in the basal part of the parasequences. The organic-rich, laminated wackestonespackstones probably formed in intertidal swamps or marshes, whereas the bioturbated, less organic-rich packstones and white wackestones with benthic foraminifers and gastropods imply deposition in intertidal to subtidal channels and more marine lagoonal environments (Sager, Winterer, Firth, et al., 1993). Maximum flooding is not well recorded, but is probably located in Core 143-866A-62R, below a lithologic change, and corresponds to a poorly sorted rudstone with small black pebbles and a large number of various benthic foraminifers.

The upper parasequence set consists of a thinning-upward sequence with a progressive disappearance of clayey levels upward. Organic matter, coalified wood fragments, and blackened elements are abundant. Thin grainstone layers appear in the upper part.

Depositional sequence 18 ( $27 \mathrm{~m}$ thick, 512-539 mbsf, Cores 143 $866 \mathrm{~A}-56 \mathrm{R}$ to $-58 \mathrm{R}$ ) has a sequence boundary located at the top of the thinning-upward parasequence set of the underlying sequence 17 . It is overlain by a $1-m$-thick clayey interval. Parasequence organization is the same as in depositional sequence 17. Clayey levels are probably well developed. Clay content decreases toward the top of sequence 18. Large foraminifers (Orbitolinids, Vercorsella) occur in Cores 143 $866 \mathrm{~A}-57 \mathrm{R}$ to $-58 \mathrm{R}$ (Arnaud-Vanneau and Sliter, this volume). Pseudomorphs of halite crystals were observed (Core 143-866A-56R).

Depositional sequence 19 (82 m thick, 430-512 mbsf, Cores $143-866 \mathrm{~A}-47 \mathrm{R}$ to $-56 \mathrm{R}$ ) has a sequence boundary that corresponds to the boundary with a low-gamma-ray signature and the boundary between packstone-grainstone levels of the underlying sequence 18 and the overlying more clayey series, characterized by a high gammaray interval.

The basal, thick parasequence set with aggradation or slight progradation is observed from Core 143-866A-56R to $-54 \mathrm{R}$, and deepening of the environments from Core 143-866A-54R upward. Marly limestones are well developed and increase in abundance upward. From the bottom to the top of parasequences, three main features were distinguished: (1) marly limestone with organic matter, coaly material, burrows (including Thalassinoides), pyrite, and blackened elements; (2) calcareous wackestone-packstone to packstone-grainstone with green algae and large benthic foraminifers (Orbitolinids, Vercorsella); and (3) hardground at the top with irregular surface and early cementation. Transgressive facies, with pyrite, abundant black pebbles or blackened elements, and other reworked clasts, are well developed. The sediments were deposited in shallow to intertidal channels and subtidal more open-marine lagoonal environments surrounding swamps or marshes covered by vegetation. Terrestrial plant debris was transported seaward by currents running in channels. Maximum flooding corresponds to the top of the most significant clayey layers (Core 143$866 \mathrm{~A}-50 \mathrm{R}$ ) with abundant organic debris, coal fragments, and large benthic foraminifers (including rare Orbitolinids).

The 250-m-thick, upper Aptian-Albian series consists of three depositional sequences, of which sequence 17 is poorly documented. At the base, sequence boundary Sb17 corresponds to a major lithologic and environmental change that may indicate a hiatus in sedimentation. Clays are abundant. The environments, which are different from those of the underlying series, grade from slightly restricted intertidal to more open-marine, shallow subtidal and are interpreted as swamps or marshes that pass seaward to quiet lagoons. Relative sea level generally seems to be a little lower than in the underlying series, and the vertical evolution very slow, from a more restricted environment in sequence 16 to a more open one in sequence 18. Facies are monotonous, but large benthic foraminifers (orbitolinids, ArnaudVanneau and Sliter, this volume) and large sponge spicules appear in this interval.

\section{Albian Carbonate Platform (Unit III, Cores 143-866A-3M to -47R)}

The interval of the Albian carbonate platform has not been studied in terms of sequence stratigraphy because of poor recovery and limited sampling. Sequence boundary Sb19 is well documented and corresponds to a sharp lithologic change. It is overlain by mudstone with ostracodes and, in Core 143-866A-47R, by a layer rich in Albian 
orbitolinids (Arnaud-Vanneau and Sliter, this volume). Above this level, recovery seems to correspond mainly to the well-lithified upper part of the parasequences, with several layers showing incipient calichification, whereas the less lithified lower part of the parasequences were not recovered. Among the recovered samples, facies with Cayeuxia, large algae, and sponge spicules are abundant and coral fragments appear upward in the section, which shows the progressive opening of the environment in the uppermost part of Hole 866A.

\section{COMPARISON WITH OTHER AREAS}

Correlations between different regions of the Tethys need a good relation between magnetostratigraphy and biostratigraphy. While data are now well detailed in some regions, difficulties remain, because regions exist where no data are available. For example, southeastern France is one of the most significant regions for ammonite zonation and sequence stratigraphy, but the Early Cretaceous stratotype sections are characterized by a very low level of paleomagnetism that hinders collecting Hauterivian-Albian paleomagnetic data. Central and northern Italy have well-known paleomagnetism and nannofossil and pelagic foraminifer zonations, but only rare ammonites have been reported. In other areas, carbonate platform series are generally dated by microfauna associations, but paleomagnetism and sequence stratigraphy are unstudied. We must discuss some stratigraphic points before proceeding with the comparison between Resolution Guyot and other Tethyan areas.

\section{Northern Tethys (France) and Apulian Plate (Italy)}

The Lower Cretaceous ammonite zonation has been developed in the western Mediterranean area, especially in France, Spain, and North Africa, for the Tethyan paleogeographic realm. The present zonation (Hoedemaeker and Bulot, 1990; Hoedemaeker et al., 1993) is now considered the standard zonation for the whole Tethyan Realm (Fig. 5). Nevertheless, in southeastern France, the Barremian/Aptian boundary is not precisely known in the stratotypes as a result of a major decrease of ammonites in the uppermost part of the Barremian section. Thus, neither the zonation proposed by Busnardo (1984), nor the standard Tethyan zonation work in that region. The recent discovery of Prodeshayesites in the Angles stratotypic section (Delanoy, 1990 ) illustrates that the Barremian/Aptian boundary is located there, a few meters below the limestone/marls lithologic boundary, because the Barremian/Aptian boundary is marked by the appearance of this genus (Birkelund et al., 1984). It follows that (1) the limestone/marls boundary is located in the lower Aptian and (2) depositional sequence Apl is in the lower Aptian and probably also most of sequence Ba5 (Fig. 5) (Jacquin et al., 1991; Arnaud and Arnaud-Vanneau, 1991).

In central Italy (Fig. 5), the Lower Cretaceous is also well developed and represented both by thick carbonate platform deposits (Chioccini and Mancinelli, 1977; Chioccini et al., 1980; Colacicchi, 1967 ) and deep-marine sedimentation (limestones of the Maiolica Formation). In the latter, the famous Gorgo a Cerbara section is one of the most interesting for comparison among paleomagnetism, nannofossils, and pelagic foraminifers (Lowrie and Alvarez, 1984; Bralower, 1987; Erba, 1988, 1992; Coccioni et al., 1992; Tarduno et al., 1992). The Barremian/Aptian boundary is not known exactly (Coccioni et al., 1992), but is located on the uppermost part of the Maiolica Formation, below the lithologic boundary between the Maiolica and Scisti a Fucoidi formations. This situation is similar to that of the southeastern France sections. Owing to this problem, the exact location of Chron M0, which is probably in the lowermost lower Aptian, cannot be correlated with the southern France sequence stratigraphy. According to Bartolocci et al. (1992), the Hauterivian/Barremian boundary is located in the M4 magnetic anomaly, owing to the presence of the ammonite association of the Angulicostata auct. Zone in the lower part of M4 interval and Hugii Zone ammonites $3 \mathrm{~m}$ above the top of M4. This location, which is well correlated with the ammonite standard zonation, is stratigraphically much below the previously published Hauterivian/Barremian boundary (Tarduno et al., 1992). For the same reasons, the lower/upper Barremian boundary is located in the upper part of M3 and M1, approximating the boundary between the Vandenheckii and Sartousiana zones.

In northern Italy, the results are similar to those of central Italy (Channell et al., 1979; Channell and Erba, 1992), but because the same microfossil zonations are applied both in central and northern Italy, the Hauterivian/Barremian boundary proposed by these authors is clearly located far below that proposed in central Italy by Bartolocci et al. (1992), as shown by new dating based on ammonite associations. This change is of greatest interest for the interpretation of carbon-isotopic curves, published in northern Italy (and for comparison with Resolution Guyot).

The lower Aptian of central Italy is characterized by the organicrich Selli level, which is interbedded in the Scisti a Fucoidi Formation and corresponds to a maximum flooding event. This level can be correlated with the Goguel organic-rich level of southeastern France (Breheret, 1988), lying just below the lower/upper Aptian boundary, in the furcata Zone of the ammonite standard zonation. This level is also loosely correlated with the appearance of the planktonic foraminifer Leupoldina cabri, which appears a few beds above the Selli level in the Gorgo a Cerbara section (Coccioni et al., 1992) and just below the Goguel level, at the base of the Marnes Bleues Formation in the Angles section (Barremian stratotypic section, Moullade, 1966; Magniez-Jannin, 1991).

Following this correlation, two "critical intervals," which are found in the Gorgo a Cerbara section and which are characterized by a decrease in abundance of planktonic fauna (Coccioni et al., 1992), may correlate with sequence boundaries SbAp2 and SbAp3 of southeastern France. In the latter region, the Goguel level corresponds to the maximum flooding of the depositional sequence Ap2, is characterized by organic-rich content in the Vocontian Trough, and passes laterally to marls (Couches supérieures à Orbitolines member) that overlie sequence boundary $\mathrm{SbAp} 2$ and fill in valleys incised on the top of the Urgonian platform (Arnaud-Vanneau and Arnaud, 1990). In the Vercors, these marls contain a rich ammonite fauna of uppermost lower Aptian belonging to the bowerbanki Zone of the boreal realm (Thieuloy and Girod, 1964; Arnaud-Vanneau, 1980), an equivalent to the furcata Zone of the new Tethyan standard zonation.

In France, the sequence stratigraphy is well known in the Vercors Massif (northern subalpine chains) and the Jura-Bas Dauphiné Platform (Jacquin et al., 1991; Arnaud and Lemoine, 1993, unpubl. data). Five features mark the evolution of this region.

1. The Hauterivian is characterized by a general high relative sea level, with two main transgressive intervals, the first one in the lowermost Hauterivian and the second in the lower part of the upper Hauterivian.

2. The Barremian and lowermost lower Aptian correspond to the shallow-water deposits of the Urgonian platform showing a general regression-transgression evolution. The maximum of regression is located at the top of the LST of depositional sequence Ba3. The transgression began with the TST of sequence $\mathrm{Ba} 3$, and the general trend grows from each maximum flooding to the next. First, the rise in relative sea level leads only to an opening of the environment (sequence $\mathrm{Ba} 4$ and $\mathrm{Ba} 5$ ). Later, the first important flooding of the platform corresponds to the "Couches inférieures à Orbitolines" member, a marly level that contains rare early Aptian ammonites.

3. The top of the Urgonian platform is contemporaneous with the top of the limestone series in the adjacent vocontian basin, which occurs into the lower Aptian.

4. On the platform, the highest sea level occurred during the sequence Ap2 maximum flooding (maximum of Aptian transgressions).

5. The upper Aptian-Albian series is represented in the basin by a thick marly formation (Marnes Bleues) with several organic-rich layers linked with maximum flooding (Goguel, Fallot, Kilian, Jacob, 

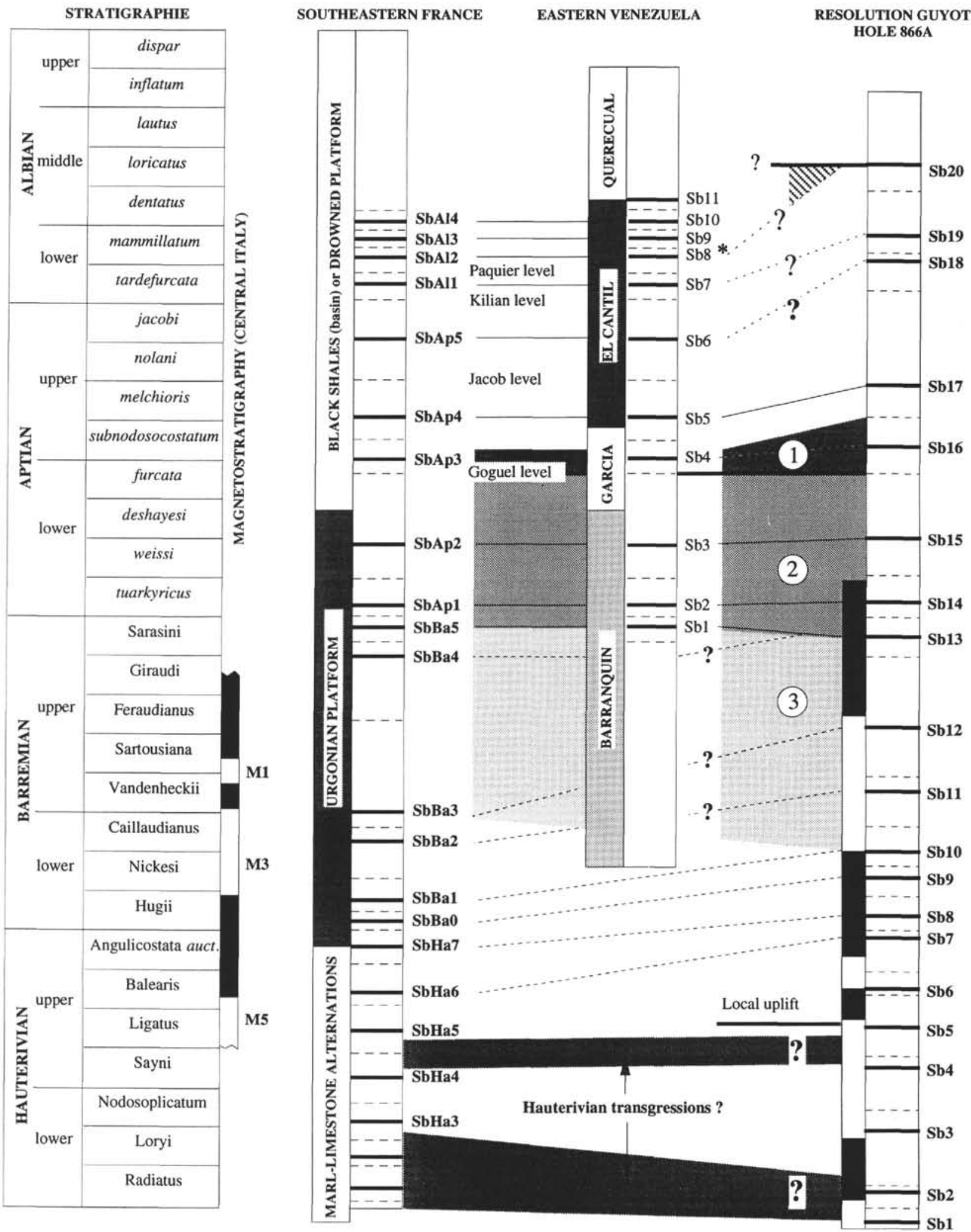

Figure 5. Correlation among the northern European margin (southeastern France), the southern margin of the Tethys (central Italy, eastern Venezuela), and the Mid-Pacific Mountains (Hole 866A). The ammonite zonation for the Lower Cretaceous of the Mediterranean region (Hoedemaeker et al., 1993) is correlated with magnetic anomalies in the upper Hauterivian-Barremian interval in central Italy (Gorgo a Cerbara section, Bartolocci et al., 1992) and southeastern France (according to Jacquin et al., 1991; Arnaud-Vanneau and Arnaud, 1991; Arnaud and Lemoine, 1993; Rubino, 1989; Bréhéret, 1988; and unpublished data). Eastern Venezuela, State Monagas, is represented by the Cerro los Encantados section and Pico Garcia section (biostratigraphy and sequence stratigraphy, L. Bulot, H. Arnaud, et al., unpubl. data). 1 = main middle Aptian transgressions; 2 = lower Aptian transgressive system; 3 = Barremian restricted marine or continental sedimentation. 
and Paquier levels; Breheret, 1988). Above the Urgonian platform, the Aptian series is incomplete and the Albian one condensed, with phosphate, glauconite, and numerous ammonites.

Some regions of southwestern France and Spain are characterized by carbonate platform deposits, which became well developed during the late Aptian and perhaps the Albian, and overlie lower Aptian marls.

\section{Southern Tethys (Venezuela)}

Southern Tethys regions are also characterized by the development of Lower Cretaceous carbonate platforms (Italy, North Africa, Venezuela) similar to that of the northern Tethys, except for two points: (1) important development of algal-microbial mats and stromatolites in central Italy and the former Yugoslavia and (2) importance of siliciclastic sedimentation interbedded with carbonate deposits, from Tunisia to Venezuela. In all of these regions, the main sea-level change is observable as, for example, in Venezuela, which is in an intermediate situation between Europe and the Mid-Pacific Mountains.

Eastern Venezuela is characterized by development along the Guyana shield of a thick Lower Cretaceous series that corresponds to sedimentation on a ramp grading from more marine environments in the north to more continental in the south. The general stratigraphy is well known (Hedberg, 1950; Rod and Maync, 1954; Guillaume et al., 1972; Macsotay, 1980; Renz, 1982; Rossi, 1985; Macellari, 1988; Potier, 1989), and much data have been collected the last few years by H. Arnaud, A. Arnaud-Vanneau, C. Beck, L. Bulot, M. Chaplet, J.-F. Sauvage, J.-F. Stephan, and V. Vivas.

The Cerro los Encantados and the Pico Garcia sections (Fig. 5), located north of Maturin in the same inner part of the Lower Cretaceous ramp, are well exposed. The Barremian-Albian series includes four main formations showing the following general evolution. The Barranquin Formation consists of a thick sandstone series in which several carbonate platform levels are interbedded in the upper part. The basal, massive sandstones were deposited in continental to shallow-marine environments, whereas the upper part of the formation corresponds to subtidal marine environments. In such a siliciclastic series, the carbonate intercalations correspond only to late TST, maximum flooding, and early HST, and the sandstones were deposited during early TST and late HST. LSTs are unknown in this inner part of the ramp. Carbonate deposits exist only in the three last depositional sequences and show a general transgressive trend toward the top of the Barranquin Formation. This lowermost Aptian evolution is similar to that described for the French Urgonian platform (see above) and for the lower part of the Peñas Altas Formation (western Venezuela, H. Arnaud, unpubl. data).

The Garcia Formation consists mainly of marls, with several ammonite-rich levels. Two depositional sequences exist, the maximum flooding of which is characterized by ammonite associations containing several species well known in the Mediterranean region: the first one belongs to the Tethyan standard furcata Zone and the second belongs to the local Aconeceras nisus assemblage Zone, which correspond to the Tethyan standard subnodosocostatum Zone (L. Bulot, pers. comm., 1993). The ammonite associations allow one to correlate these maximum flooding occurrences with sequence Ap2 (Goguel level) and sequence Ap3 maximum flooding in southeastern France. On the other hand, the Garcia Formation corresponds clearly to the Aptian transgressions, when the Venezuelan platform was drowned and characterized by deeper marine environments.

The El Cantil Formation consists of a thick carbonate platform series, with sandstones as a minor component. As in the Barranquin Formation, the sandstones exist only in the lowermost and uppermost parts of the depositional sequences (early TST and late HST). Six depositional sequences are known, with a general aggradational disposition, except for the last one, just below the Querecual Formation and characterized by a deepening environment. The Querecual Formation consists of organic-rich limestone and marly limestone depos- ited in deeper marine environments during middle and late Albian transgressions, and later during the Late Cretaceous.

\section{Mid-Pacific Mountains (Resolution Guyot)}

The stratigraphy at Hole $866 \mathrm{~A}$, determined from a compilation of micropaleontology data, carbon-isotope study, and radiometric dates, is shown in Figure 5. Radiometric ages for the basalts that lie below the carbonate platform range from 120 to $128 \mathrm{Ma}$ (Pringle et al., this volume) and correspond to the Barremian (Harland et al., 1990), Barremian/Hauterivian (Harland et al., 1982), or to Hauterivian/ Valanginian (Odin and Odin, 1990).

The carbon-isotope curve and its comparison with northern Italian sections (Jenkyns, this volume) shows that the Hauterivian/Barremian boundary is located within Unit VIII, 100 to $200 \mathrm{~m}$ above the top of the basalt, whereas the Barremian/Aptian boundary lies at about $900 \mathrm{mbsf}$ and the Aptian/Albian boundary is close to $500 \mathrm{mbsf}$. According to the new stratigraphic data from central Italy discussed above, the proposed Hauterivian/Barremian boundary should be moved upward.

Poor microfauna assemblages exist in the Resolution Guyot section; nevertheless, Hauterivian populations were found from the bottom to Core 143-866A-142R, upper Aptian fauna from Cores 143866A-82R through -52R, and middle to upper Albian fauna from Core 143-866A-51 to the top of the calcareous series (Arnaud-Vanneau and Sliter, this volume). The Barremian and lower Aptian are not characterized by microfauna associations because of the very restricted shallow-marine environments, so the Barremian/Aptian boundary could be moved down and the Hauterivian/Barremian boundary moved up in Hole 866A. Lower Aptian rudists are present in depositional sequence 14 (J.-P. Masse, pers. comm., 1993).

The paleomagnetic record from $900 \mathrm{mbsf}$ to the bottom (Tarduno, this volume) indicates that the Hauterivian/Barremian boundary, which is located within the M4 normal interval, may correspond to the interval at 1204-1324 mbsf. All of the sequence boundaries at Hole 866 A correlate to lack of sedimentation. Anomaly M2 is missing on Resolution Guyot. In the eastern Tethys (France), a thick depositional sequence can be seen with a major LST for all of the lower part of the upper Barremian (sequence Ba3, Pl. 1, Fig. 10). If the LST is missing, as it is the case for Resolution Guyot, the M2 anomaly is not represented and M1 occurs directly above M3 (as proposed in Fig. 5).

Both isotopic data and micropaleontology indicate that the lower/ upper Aptian boundary is located between 750 and $800 \mathrm{mbsf}$. According to Jenkyns (this volume), correlation of the carbon-isotope curve between Hole 866A and the well-dated Aptian section of northern Italy shows that the interval at $755-840$ mbsf corresponds to the Leupoldina cabri Zone, which begins (see above) just below the lower/upper Aptian boundary. These data prove that the depositional sequence 15 maximum flooding is exactly equivalent to the Selli and Goguel levels and that sequence 15 (Resolution Guyot) can be correlated with sequence Ap2 of southeastern France.

At Site 463, $40 \mathrm{~km}$ east of Hole 866A (Thiede et al., 1981; Shipboard Scientific Party, 1981), a lower Aptian organic-rich level occurs in Core 62-463-70 (Mélières et al., 1981) and may correlate with sequence 15 . In addition, volcanic ash was observed between Cores 62-463-67 and 62-463-71, just above the magnetic anomaly M0, which is seen in Core 62-463-72 (Sayre, 1981; Tarduno et al., 1989). On Resolution Guyot, volcanic glass exists at least between Cores 143-866A-87R and $-89 \mathrm{R}$, so that M0 could be located in the lowermost part of sequence 15 , or at about the sequence boundary Sb15. These correlations imply that the land-derived organic-rich layer observed in Core 143-866A-89R is not at the same level as that in Core $62-463-70$, that it does not have the same significance, and that it cannot be correlated with the Selli level.

Higher in the Hole 866 A section, carbon-isotope curves allow Jenkyns (this volume) to correlate the interval at 595-795 mbsf to the range of the ferreolensis, algerianus, and trochoidea pelagic foraminifer zones of northern Italy, the distribution that corresponds to the 
subnodosocostatum, melchioris, nolani, and jacobi zones of the Tethyan ammonite standard zonation. Based on these correlations, sequence boundary Sb17 falls near the subnodosocostatum/melchioris zonal boundary (or algerianus/trochoides zonal boundary) and, for that reason, could be correlated with SbAp4 of southeastern France. If this correlation is sound, the sequence boundary SbAp3, well known in France, appears to have a similar location to sequence boundary Sb16 on Resolution Guyot. In the upper part of Hole 866A, long-range correlation is too speculative, owing to the absence of data and poor core recovery.

A comparison between Resolution Guyot and other distant northern or southern regions of the Tethys shows a good correlation for the main events and large-scale changes in relative sea level. Resolution Guyot, as well as several other Tethyan areas, documents five main features: (1) the Hauterivian corresponds to open-marine environments, with two relative deepenings at the bottom and in the middle part that can be linked with Hauterivian transgressions; (2) very restricted shallow-marine Barremian series, with thick aggrading sequences; (3) progressive deepening during the early Aptian, with the appearance of shallow, open-marine waters on the guyot; (4) an early Aptian transgression (sequences 14 and 15), characterized by predominantly open-marine deposits; (5) return to more shallow-marine and restricted environments during the late Aptian; and (6) new transgressive period during the Albian, with the development of shallow, open-marine environments.

These conclusions show that sedimentation on the Resolution Guyot is influenced largely by sea-level variations that were also registered in other distant areas. On the other hand, some of the main lithologic changes observed on Resolution Guyot (Sb5, Sb10, and Sb20) appear to be the result of local conditions only. Sb5 may correspond to local uplift.

\section{CONCLUSIONS}

Resolution Guyot, in the Mid-Pacific Mountains, is now well characterized for the 1619-m-thick, complete Hauterivian-Albian carbonate sequence that was cored between basalt basement and the Upper Cretaceous-Cenozoic thin pelagic cap.

Compilation of the results of the Scientific Party (magnetic anomalies, biostratigraphic data, carbon-isotope curve, organic matter content, radiometric dating, etc.) and comparison with other Tethyan areas allow us to place the Hauterivian/Barremian boundary close to 1250 to $1300 \mathrm{mbsf}$, the Barremian/Aptian boundary at about 950 mbsf, and lower/upper Aptian boundary close to 760 mbsf (Fig. 6).

The Hauterivian-Aptian series consists of 18 depositional sequences, each characterized by transgressive systems tracts, maximum flooding surfaces, and highstand systems tracts, whereas lowstand systems tracts are missing, according to the stratal pattern and facies distribution.

Four depositional sequence sets were distinguished (Figs. 4 and 6). The Hauterivian sequences 1 to 4 are characterized by oolitic or oolitic/oncoidal sediments deposited in open-marine environments and by massive dolomitization that occurs in several levels. The general trend is cyclic, transgressive just above basaltic basement, then slightly regressive, then transgressive again in sequence 4 . This interval corresponds to the establishment of a carbonate platform and progressive flooding of a probably nearly flat volcanic island. Owing to the absence of a lowstand systems tract, the marine sedimentation probably began earlier on the edge of Resolution Guyot than it did at Hole $866 \mathrm{~A}$.

The second set consists of eight depositional sequences (sequences 5 through 12) that have (1) an emersion level at the bottom (Sb5), linked with a major downward shift and the appearance of restricted shallow-marine environments; (2) a lower part (sequences 5 through 9) that is characterized by little progradation, restricted environments, and more open-marine maximum flooding; (3) an upper aggrading part (sequences 10 to 12), where the most restricted facies of the entire Hole 866A series occur; and (4) a general thickening-upward disposition of the sequences.

The third sequence set consists of four Aptian depositional sequences (sequences 13 through 16) showing (1) the appearance and progressive upward development of open-marine environments, (2) a general backstepping and thickening-upward disposition of the depositional sequences, and (3) the presence of two main transgressions. The first one (into sequence 14) probably correlates with the "Couches inférieures à Orbitolines" of southeastern France, "Livello ad Palorbitolina" of central Italy platforms, and some Palorbitolina beds of Europe and North Africa (Tunisia and eastern Algeria). The second one (into sequence 15 ) is precisely correlated with the late early Aptian maximum flooding, well known from Europe to South America both on platforms ("Couches supérieures à Orbitolines") and in basins, where it corresponds to an organic-rich layer (Goguel and Selli levels).

The fourth sequence set includes sequences 17 to 19 (upper Aptian to Albian) and shows (1) an abrupt return to restricted shallow environments that grade from swamps and marshes to shallow-marine lagoonal and (2) a general aggrading and monotonous disposition of sequences and parasequences.

These results indicate that sedimentation on Resolution Guyot was subject to relative sea-level variations of different magnitudes, the most important of which appears clearly to be of worldwide significance. The situation at Hole $866 \mathrm{~A}$ was no different from that at stable areas, such as eastern Venezuela on the northern part of the Guyana shield or regions characterized by minor instability, such as carbonate platforms from the European (southeastern France) or Apulian (central Italy) margin of the Ligurian Tethys. Here also, sedimentation was subjected more to sea-level changes than to subsidence variations.

Rates of sedimentation, and therefore rates of subsidence, are no higher in the Mid-Pacific Mountains than in other regions of the Tethys: about $360 \mathrm{~m}$ for the Hauterivian (according to the time scale proposed by Harland et al., 1990, 1982; and Odin and Odin, 1990: 120,60 , or $60 \mathrm{~m} / \mathrm{m} . y$. , respectively), $300 \mathrm{~m}$ for the Barremian $(50,50$, or $150 \mathrm{~m} / \mathrm{m} . \mathrm{y}$.), $450 \mathrm{~m}$ for the Aptian $(32,75$, or $75 \mathrm{~m} / \mathrm{m} . \mathrm{y}$.) and 500 $\mathrm{m}$ for the Albian $(36,32$, or $41 \mathrm{~m} / \mathrm{m}$.y.) on Resolution Guyot. The sedimentation rate at Hole $866 \mathrm{~A}$ was sufficiently high to continuously fill in the space created by tectonic subsidence during 35 m.y. (Hauterivian-Albian). For these reasons, the most impressive feature of Resolution Guyot is not the high subsidence rates, but the extensive development of very restricted shallow subtidal to intertidal environments (algal-microbial mats,.etc.) within such a small-sized carbonate platform. The thick Hauterivian-Albian series consists only of carbonate platform deposits. This arrangement of sediment type and facies is known from only a few regions of the Tethys, especially on the Apulian Plate, for example, in central and southern Italy (Colacicchi, 1967; H. Arnaud, unpubl. data), where well-developed inner-platform facies, such as algal-microbial mats, stromatolites, and mudstone with bird's eyes, exist as far as the top of the bypass bank margin. Other than for the size of the platform, this locality could be an exact counterpart to Resolution Guyot.

\section{ACKNOWLEDGMENTS}

We thank all of the participants of Leg 143 who made it possible to sample the recovered rocks and who helped to elaborate some of the hypotheses presented here. H.A. acknowledges the financial support of the French Centre National de la Recherche Scientifique and INSU, and A.S. acknowledges the support of the Swiss National Science Foundation. We thank E.J. Winterer and the ODP editor for their critical reading. Also acknowledged are the helpful comments of an anonymous reviewer and W. Schlager. We also thank M. Argot and F. Ardito for preparing samples, photographs, and plates. 

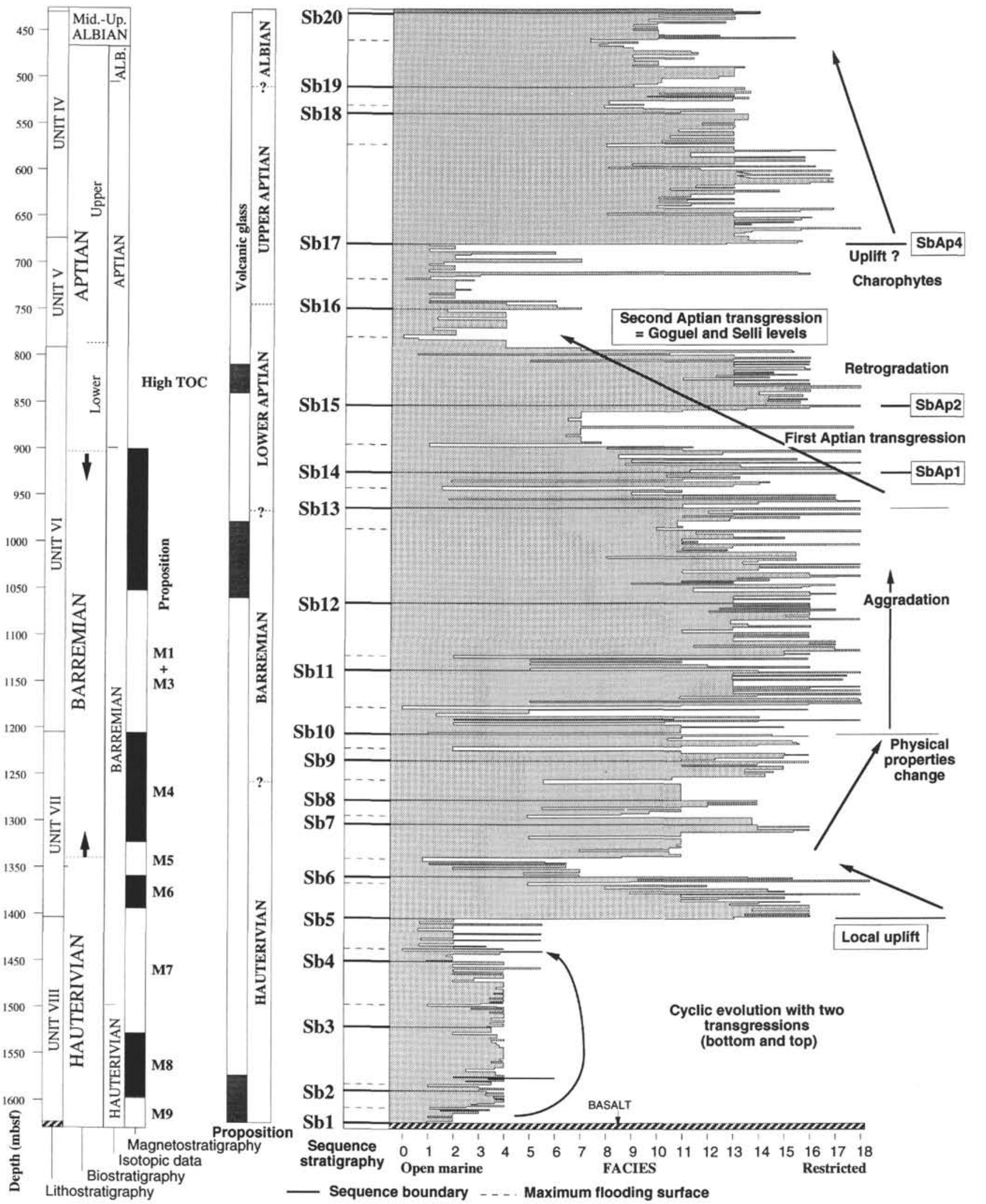

$\mathrm{Sb2}$

Sb1 $\begin{array}{clllllllllllllllllll}\begin{array}{c}\text { Sequence } \\ \text { stratigraphy }\end{array} & \begin{array}{l}0 \\ \text { Open marine }\end{array} & 2 & 4 & 5 & 6 & 7 & 8 & 9 & 10 & 11 & 12 & 13 & 14 & 15 & 16 & 17 & 18 \\ \text { Restricted }\end{array}$ - Sequence boundary _. . . Maximum flooding surface

Figure 6. Vertical evolution and sequence stratigraphy of the Hauterivian-Albian series drilled on Resolution Guyot (Hole 866A): lithostratigraphy after Sager, Winterer, Firth, et al. (1993); biostratigraphy (foraminifers) after Arnaud-Vanneau and Sliter (this volume); isotopic data after Jenkyns (this volume); magnetostratigraphy after Tarduno (this volume); organic matter, after Baudin et al. (this volume). The proposed correlation of magnetic anomalies and stage or substage boundaries is based on sequence stratigraphy correlation. On the sequence stratigraphy column, only TST (below mfs) and HST (above mfs) are represented. SbAp1, SbAp2, and SbAp3 = proposed correlations between Resolution Guyot and southeastern France. 


\section{REFERENCES}

Arnaud, H., and Arnaud-Vanneau, A., 1989. Séquences de dépôt et variations du niveau relatif de la mer au Barrémien et à l'Aptien inférieur dans les massifs subalpins septentrionaux et le Jura (SE de la France). Bull. Soc. géol. Fr., 8:651-660.

1991. Les Calcaires urgoniens des Massifs subalpins septentrionaux et du Jura (France): âge et discussion des données stratigraphiques. Géol. Alp., 67:63-79.

Arnaud, H., and Lemoine, M., 1993. Structure and Mesozoic-Cenozoic evolution of the South-East France Basin (SFB). Géol. Alp. Spec. Ser, 3:3-58.

Arnaud-Vanneau, A., 1980. Micropaléontologie, paléoécologie et sédimentologie d'une plate-forme carbonatée de la marge passive de la Téthys: l'Urgonien du Vercors septentrional et de la Chartreuse (Alpes occidentales). Géol. Alp., 10.

Arnaud-Vanneau, A., and Arnaud, H., 1990. Hauterivian to Lower Aptian carbonate shelf sedimentation and sequence stratigraphy in the Jura and northern Subalpine chains (southeastern France and Swiss Jura). In Tucker, M.E., Wilson, J.L., Crevello, P.D., Sarg, J.R., and Read, J.F. (Eds.), Carbonate Platforms: Facies, Sequences and Evolution. Spec. Publ. Int. Assoc. Sedimentol., 9:203-233.

1991. Sédimentation et variations relatives du niveau de la mer sur les plates-formes carbonatées du Berriasien-Valanginien inférieur et du Barrémien dans les massifs subalpins septentrionaux et le Jura (SE de la France). Bull. Soc. géol. Fr., 162:535-545.

Arnaud-Vanneau, A., Arnaud, H., Meunier, A.R., and Seguin, J.-C., 1987 Caractères des transgressions du Crétacé inférieur sur les marges de l'Océan Ligure (SE de la France et Italie centrale). Mem. Geol. Univ. Dijon. 11:167-182.

Bartolocci, P., Beraldini, M., Cecca, F., Faraoni, P., Marini, A., and Pallini, G., 1992. Preliminary results on correlation between Barremian ammonites and magnetic stratigraphy in Umbria-Marche Apennines (Central Italy). Paleopelagos, 2:63-68.

Birkelund, T., Hancock, J.M., Hart, M.B., Rawson, P.F., Remane, J., Robaszynski, F., Schmid, F., and Surlyk, F., 1984. Cretaceous stage boundaries-proposals. Bull. Geol. Soc. Den., 33:3-20.

Bralower, T.J., 1987. Valanginian to Aptian calcareous nannofossil stratigraphy and correlation with the Upper $\mathrm{M}$-sequence magnetic anomalies. Mar. Micropaleontol., 11:293-310.

Bréhéret, J.-G., 1988. Episodes de sédimentation riche en matière organique dans les marnes bleues d'âge Aptien de la partie pélagique du bassin vocontien. Bull. Soc. géol. Fr., 8:349-356.

Busnardo, R., 1984. Echelles stratigraphiques du Crétacé inférieur, Ammonites. In Debrand-Passard, S., Courbouleix, S., and Lienhardt, M.J. (Eds.), Synthèse Géologique du Sud-Est de la France. Mem. Bur. Rech. Geol. Min., 125:291-293.

Channell, J.E.T., and Erba, E., 1992. Early Cretaceous polarity chrons CMO to $\mathrm{CM} 1 \mathrm{I}$ recorded in northern Italian land sections near Brescia (Northern Italy). Earth. Planet. Sci. Lett., 108:161-179.

Channell, J.E.T., Lowrie, W., and Medizza, F., 1979. Middle and Early Cretaceous magnetic stratigraphy from the Cismon section, northern Italy. Earth Planet. Sci. Lett., 42:153-166.

Chioccini, M., Losego, L., Mancinelli, A., and Romano, A., 1980. Ricerche geologiche sul Gran Sasso d'Italia (Abruzzo). Evoluzione paleogeografica, durante il Giurasico superiore ed il Cretacico inferiore, del margine della Piattaforma carbonatica nell area tra Barisciano e Castel del Monte. Stud. Geol. Camerti, 6:55-80.

Chioccini, M., and Mancinelli. A., 1977. Microbiostratigrafia del Mesozoico in facies di piattaforma carbonatica dei Monte Aurunci (Lazio meridionale). Stud. Geol. Camerti, 3:109-152.

Coccioni, R., Erba, E., and Premoli-Silva, I., 1992. Barremian-Aptian calcareous plankton biostratigraphy from the Gorgo Cerbara section (Marche, central Italy) and implications for plankton evolution. Cretaceous Res., 13:517-537.

Colacicchi, R., 1967. Geologia della Marsica orientale. Geol. Rom., 6:189-316.

Delanoy, G., 1991. Sur la présence du genre Prodeshayesites Casey, 1961 (Ammonoïdea) dans l'Aptien inférieur du Bassin Vovontien. Cretaceous Res., 12:437-441.

\footnotetext{
Abbreviations for names of organizations and publications in ODP reference lists follow the style given in Chemical Abstracts Service Source Index (published by American Chemical Society).
}

Erba, E., 1988. Aptian-Albian calcareous nannofossil biostratigraphy of the Scisti a Fucoidi cored at Piobbico (Central Italy). Riv. Ital. Paleontol. Stratigr., 94:249-284.

1992. Calcareous nannofossil distribution in pelagic rhythmic sediments (Aptian-Albian Piobbico core, Central Italy). Riv. Ital. Paleontol. Stratigr., 97:455-484.

Guillaume, H.A., Bolli, H.M., and Beckmann, J.P., 1972. Estratigrafia del Cretaceo inferior en la Serrania del interior, oriente de Venezuela. 4th Congreso Geologico Venezolano, Caracas 1972, 3:1619-1658.

Halley, R.B., Harris, P.M., and Hine, A.C., 1983. Bank margin environment. In Sholle, P.A., Bebout, D.G., and Moore, C.H. (Eds.), Carbonate Depositional Environments. AAPG Mem., 33:211-265.

Haq, B.U., Hardenbol, J., and Vail, P.R., 1987. The new chronostratigraphic basis of Cenozoic and Mesozoic sea level cycles. Spec. Publ. Cushman Found. Foraminiferal Res., 24:7-13.

-1988. Mesozoic and Cenozoic chronostratigraphy and cycles of sea-level change. In Wilgus, C.K., Hastings, B.S., Kendall, C.G.St.C., Posamentier, H.W., Ross, C.A., and Van Wagoner, J.C. (Eds.), Sea-Level Changes-An Integrated Approach. Spec. Publ.-Soc. Econ. Paleontol. Mineral., 42:72-108.

Harland, W.B., Armstrong, R.L., Cox, A.V., Craig, L.E., Smith, A.G., and Smith, D.G., 1990. A Geologic Time Scale 1989: Cambridge (Cambridge Univ. Press).

Harland, W.B., Cox, A.V., Llewellyn, P.G., Pickton, C.A.G., Smith, A.G., and Walters, R., 1982. A Geologic Time Scale: Cambridge (Cambridge Univ. Press).

Hedberg, H.D., 1950. Geology of the Eastern Venezuela Basin (Anzoategui, Monagas, Sucre, eastern Guarico portion). Geol. Soc. Am. Bull., 61:19712024.

Hoedemaeker, P.J., and Bulot, L., 1990. Preliminary ammonite zonation for the Lower Cretaceous of the Mediterranean Region. Geol. Alp., 66:123-127.

Hoedemaeker, P.J., Company, M., Aguirre-Urreta, M.B., Avram, E., Bogdanova, T.N., Bujtor, L., Bulot, L., Cecca, F., Delanoy, G., Ettachfini, M., Memmi, L., Owen, H.G., Rawson, P.F., Sandoval, J., Tavera, J.M., Thieuloy, J.P., Tovbina, S.Z., and Vasicek, Z., 1993. Ammonite zonation for the Lower Cretaceous of the Mediterranean region; basis for the stratigraphic correlations within IGCP-Project 262. Rev. Esp. Paleontol., 8:117-120.

Inden, R.F., and Moore, C.H., 1983. Beach environment. In Scholle, P.A., Bebout D.G., Moore, C.H. (Eds.), Carbonate Depositional Environments. AAPG Mem., 33:211-265.

Jacquin, T., Arnaud-Vanneau, A., Arnaud, H., Ravenne, C., and Vail, P.R., 1991. Systems tracts and depositional sequences in a carbonate setting: a study of continuous outcrops from platform to basin at the scale of seismic lines. Mar. Pet. Geol., 8:122-139.

Lowrie, W., and Alvarez, W., 1984. Lower Cretaceous magnetic stratigraphy in Umbrian pelagic limestone sections. Earth Planet. Sci. Lett., 71:315328.

Macellari, C.E., 1988. Cretaceous paleogeography and depositional cycles of western South America. J. South Am. Earth Sci., 1:373-418.

Macsotay, O., 1980. Mollusques benthiques du Crétacé inférieur: une méthode de corrélation entre la Téthys mésogéenne et le domaine paléo-Caraibe (Vénézuela) [Thesis]. Lyon Univ., France.

Magniez-Jannin, F., 1991. Renouvellements de foraminiferes et séquences de dépôt dans le Crétacé inférieur du Bassin vocontien (SE de la France). Bull. Soc. géol. Fr., 162:887-895.

Masse, J.-P., 1976. Les calcaires urgoniens de Provence (Valanginien-Aptien inférieur). Stratigraphie, Paléontologie, les environnements et leur évolution. [Thèse doct. sci.] Univ. Aix-Marseille II, France.

Mélières, F., Deroo, G., and Herbin, J.-P., 1981. Organic-matter-rich and hypersiliceous Aptian sediments from western Mid-Pacific Mountains, Deep Sea Drilling Project Leg 62. In Thiede, J., Vallier, T.L., et al., Init. Repts. DSDP, 62: Washington (U.S. Govt. Printing Office), 903-915

Moullade, M., 1966. Etude stratigraphique et micropaléontologique du Crétacé inférieur de la "fosse vocontienne." Doc. Lab. Geol. Fac. Sci. Lyon, 15:1-369.

Odin, G.-S., and Odin, C., 1990. Echelle numérique des temps géologiques. Géochronique, 35:12-20.

Potier, G., 1989. La Serrania del Interior Oriental sur le transect Cumana-Urica et le bassin de Maturin (Vénézuela) [Thesis]. Univ. of Bretagne, France.

Purser, B.H., 1983. Sédimentation et Diagenèse des Carbonates Néritiques Récents: Paris (Technip Ed.).

Renz, O., 1982. The Cretaceous Ammonites of Venezuela: Basel (Birkhaüser Verlag). 
Rod, E., and Maync, W., 1954. Revision of the Lower Cretaceous stratigraphy of Venezuela. AAPG Bull., 38:193-283.

Rossi, T., 1985. Contribution à l'étude géologique de la frontière sud-est de la plaque Caraibe: la Serrania del Interior oriental sur le transect CariacoMaturin [Thesis]. Univ. of Bretagne, France.

Rubino, J.-L., 1989. Introduction remarks on Upper Aptian to Albian siliciclastic/carbonate depositional sequences. Mesozoic Eustacy Record on Western Tethyan Margins, Lyon, 23rd-24th November 1989, 28-45.

Sager, W.W., Winterer, E.L., Firth, J.V., et al., 1993. Proc. ODP, Init. Repts., 143: College Station, TX (Ocean Drilling Program).

Sarg, J.F., 1988. Carbonate sequence stratigraphy. In Wilgus, C.K., Hastings, B.S., Kendall, C.G.St.C., Posamentier, H., Ross, C.A., and Van Wagoner, J. (Eds.), Sea-Level Changes: An Integrated Approach. Spec. Publ.-Soc. Econ. Paleontol. Mineral., 42:155-181.

Sayre, W.O., 1981. Preliminary report on the paleomagnetism of Aptian and Albian limestones and trachytes from the Mid-Pacific Mountains and Hess Rise, Deep Sea Drilling Project Leg 62. In Thiede, J., Vallier, T.L., et al., Init. Repts. DSDP, 62: Washington (U.S. Govt. Printing Office), 983-994.

Schlager, W., 1981. The paradox of drowned reefs and carbonate platforms. Geol. Soc. Am. Bull., 92:197-211.

Shinn, E.A., 1983. Tidal flat environment. In Scholle, P.A., Bebout, D.G., and Moore, C. H. (Eds.), Carbonate Depositional Environments. AAPG Mem., 33:171-210.

Shipboard Scientific Party, 1981. Site 463: western Mid-Pacific Mountains. In Thiede, J., Vallier, T.L., et al., Init. Repts. DSDP, 62: Washington (U.S. Govt. Printing Office), 33-156.

Tarduno, J.A., Lowrie, W., Sliter, W.V., Bralower, T.J., and Heller, F., 1992. Reversed polarity characteristic magnetizations in the Albian Contessa section, Umbrian Apennines, Italy: implications for the existence of a mid-Cretaceous mixed polarity interval. J. Geophys. Res., 97:241-271.

Tarduno, J.A., Sliter, W.V., Bralower, T.J., McWilliams, M., Premoli Silva, I., and Ogg, J.G., 1989. M-sequence reversals recorded in DSDP sediment cores from the western Mid-Pacific Mountains and Magellan Rise. Geol. Soc. Am. Bull., 101:1306-1316.

Thiede, J., Vallier, T.L., and Adelseck, C.G., 1981. Deep Sea Drilling Project Leg 62, North Central Pacific Ocean: introduction, cruise, narrative, principal results, and explanatory notes. In Thiede, J., Vallier, T.L., et al., Init. Repts. DSDP, 62: Washington (U.S. Govt. Printing Office), 5-31.

Thieuloy, J.-P., and Girod, J.-P., 1964. L'Aptien et l'Albien fossiliferes du synclinal d'Autrans (Vercors septentrional). Trav. Lab. Geol. Univ. Grenoble, 40:92-111.

Vail, P.R, and Todd, R.G., 1981. North Sea Jurassic unconformities, chronostratigraphy, and sea-level changes from seismic stratigraphy. In Illing, L.V., and Hobson, G.D. (Eds.), Proc. Petroleum Geology of the Continental Shelf, Northwest Europe Conf., 216-235.

Van Wagoner, J.C., Posamentier, H.W., Mitchum, R.M., Jr., Vail, P.R., Sarg, J.F., Loutit, T.S., and Hardenbol, J., 1988. An overview of the fundamentals of the sequence stratigraphy and key definitions. In Wilgus, C.K., Hastings, B.S., Ross, C.A., Posamentier, H.W., Van Wagoner, J.C., and Kendall, C.G.St.C., (Eds.), Sea-Level Changes: an Integrated Approach. Spec. Publ.-Soc. Econ. Paleontol. Mineral., 42:39-45.

Date of initial receipt: 30 November 1993

Date of acceptance: 9 May 1994

Ms143SR-230 

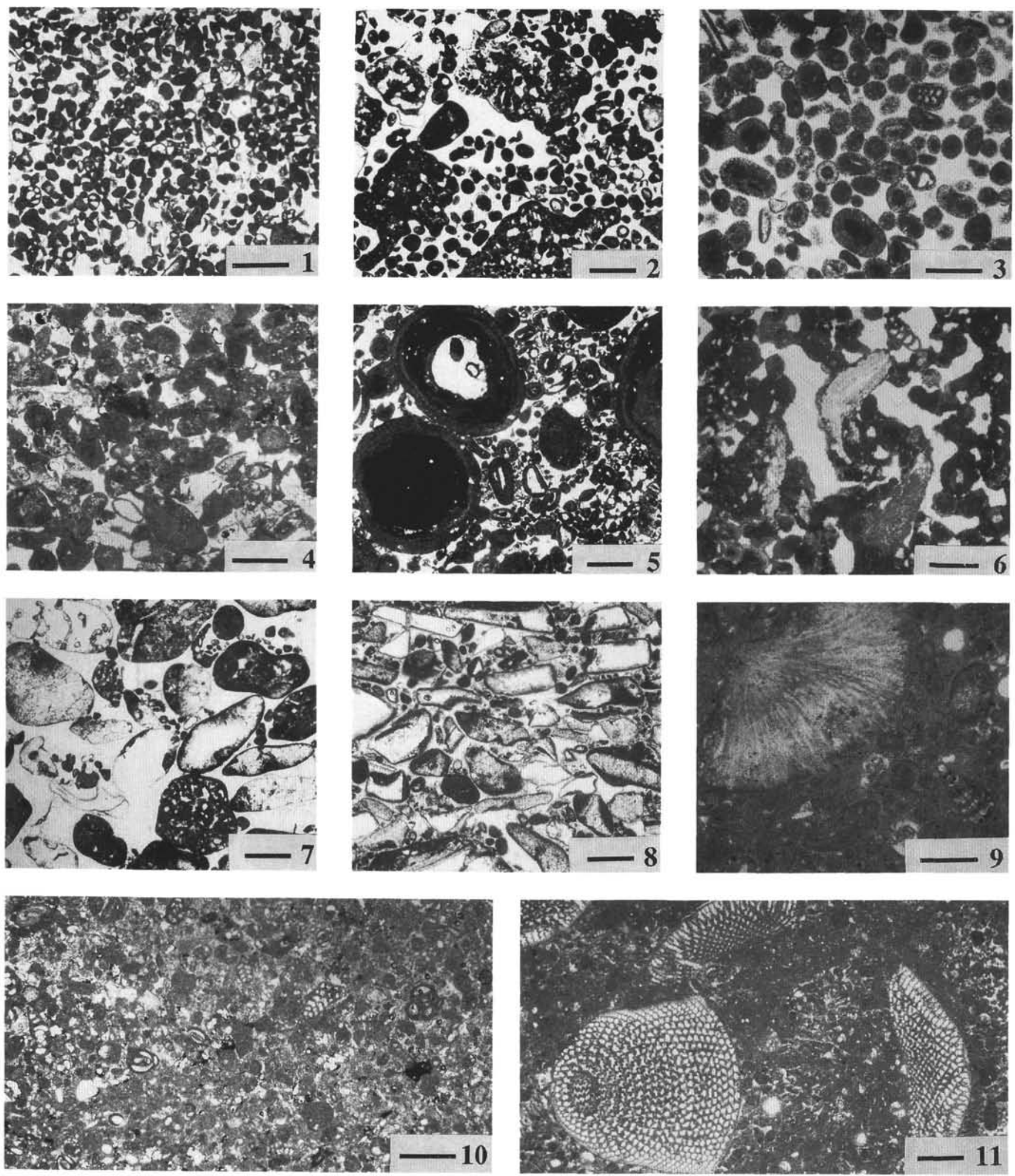

Plate 1. Photomicrographs (nonpolarized light) of carbonate facies. 1. Facies 0 (Sample 143-866A-76R-3, 10-13 cm; scale 0.25 mm). 2. Facies 1 (Sample 143-866A-170R-5, 10-13 cm; scale 0.25 mm). 3. Facies 2 (Sample 143-866A-149R-1, 72-74 cm; scale 0.25 mm). 4. Facies 3 (Sample 143-866A-76R-2, $62-66 \mathrm{~cm}$; scale $0.25 \mathrm{~mm}$ ). 5. Facies 4 (Sample 143-866A-156R-1, 81-85 cm; scale 0.25 mm). 6. Facies 5 (Sample 143-866A-125R-3, 61-62 cm; scale 0.25 mm). 7. Facies 6 (Sample 143-866A-143-866A-74R-3, 55-57 cm; scale 0.25 mm). 8. Facies 7 (Sample 143-866A-93R-1, 17-19 cm; scale 0.25 mm). 9. Facies 8 (Sample 143-866A-76R-1, 28-32 cm; scale 0.25 mm). 10. Facies 9, with miliolids and Vercorsella (Sample 143-866A-25R-1, 53-55 cm; scale 0.25 mm). 11. Facies 10 with orbitolinids n. gen. n. sp. (Sample 143-866A-47R-1, 66-68 cm; scale $0.25 \mathrm{~mm}$ ). 

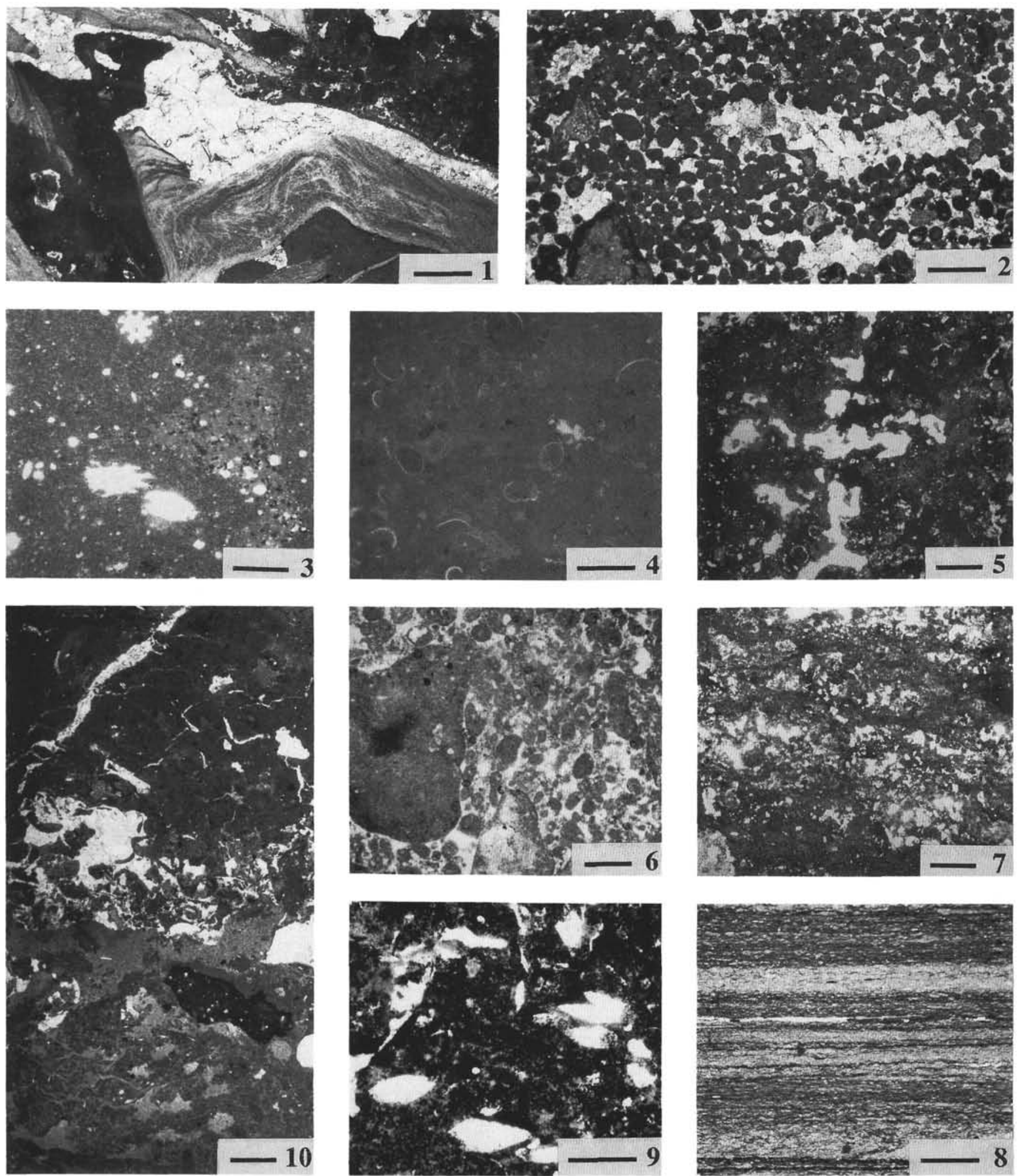

Plate 2. Photomicrographs (nonpolarized light) of carbonate facies. 1. Facies 11, with rudist shell (Sample 143-866A-105R-1, 82-84 cm; scale 0.16 cm). 2. Oosparite with keystone vugs (Sample 143-866A-125R-3, 71-73; scale 0.125 cm). 3. Facies 12 (Sample 143-866A-103R-1, 8-10 cm; scale 0.25 mm). 4. Facies 13 (Sample 143-866A-31R-1, 56-58 cm; scale 0.25 mm). 5. Facies 14 (Sample 143-866A-124R-1, $62-64 \mathrm{~cm}$; scale $0.25 \mathrm{~mm}$ ). 6. Facies 15 (Sample 143-866A-106R-1, 52-54 cm; scale 0.25 mm). 7. Facies 16 (Sample 143-866A-7IR-1, 108-110 cm; scale 0.25 mm). 8. Facies 17 (Sample 143-866A-118R-1, $18-20 \mathrm{~cm}$; scale $0.8 \mathrm{~cm}$ ). 9. Facies 17, with pseudomorphs of gypsum (Sample 143-866A-109R-1, 16-18 cm; scale 0.25 mm). 10. Facies 18, with desiccation cracks (Sample 143-866A-89R-1, 86-87 cm; scale 0.25 mm). 